\title{
In the Labyrinth of the Library: Petrarch's Cicero, Dante's Virgil, and the Historiography of the Renaissance
}

\author{
by MARTIN EISNER
}

Petrarch's 1345 discovery of Cicero's personal letters in Verona has long been regarded as a foundational moment in the historiography of the Renaissance. In the traditional view, Petrarch's discovery engenders a new historical self-consciousness that has frequently been described, since the middle of the twentieth century, in terms of a contrast between a medieval Dante and a Renaissance Petrarch. In keeping with recent work rethinking periodization, this essay revisits Petrarch's letters on his discovery to reconsider the distance between Dante and Petrarch and to reveal how Petrarch constructs his new relationship with Cicero through Dante's characterization of Virgil. While some critics have noted this Dantean presence, they have not examined its meaning. This study argues that Petrarch's borrowing from Dante is significant because it shows how Dante's complex relationship to the past embodied in the figure of Virgil shaped Petrarch's construction of his Cicero and informed Renaissance ideas of history.

\section{INTRODUCTION}

$\mathrm{P}$ etrarch's 1345 discovery of Cicero's personal letters in Verona has long been regarded as a foundational moment in the historiography of the Renaissance, whether one takes the term as referring only to a movement associated with humanism or to the period that also goes by the name early modern. ${ }^{1}$ From Leonardo Bruni (1370-1444) to modern histories of scholarship and Western civilization textbooks, Petrarch's discovery represents a primal scene that has been linked to other putative Renaissance discoveries of the individual, ideas of authorship, the stylistic principle of imitatio, and, most importantly for

${ }^{1}$ For the distinction between the Renaissance as movement or as period, see Gombrich. The association of the revival of antiquity with the Renaissance has been challenged at least since Burckhardt pointedly delayed his treatment of "The Revival of Antiquity" until part 3 of The Civilization of the Renaissance in Italy, but "even the broadest formulations [of the term Renaissance] rarely lose sight of the common denominator of a renewed interest in and engagement with the culture of the classical past": Houghton, 17. One example of the conflation is Kristeller, 1979, 87. 
this essay, the past. ${ }^{2}$ Since the middle of the twentieth century Petrarch's much-celebrated new historical self-consciousness has frequently been described in terms of a contrast between a medieval Dante and a Renaissance Petrarch. ${ }^{3}$ Whereas earlier accounts of the revival of classical culture, from Boccaccio (1313-75) and Bruni through Jacob Burckhardt (1818-97), tend to associate Dante and Petrarch, most recent scholarship has followed Theodor E. Mommsen's thesis in his classic study "Petrarch's Conception of the Dark Ages," where he remarks that "to realize the peculiarity of Petrarch's standpoint, we have only to think of the entirely different picture of the past in the Divine Comedy, where Dante usually couples ancient and mediaeval figures in his representation of the various vices and virtues of man." "The contrast continues in Thomas Greene's influential The Light in Troy, where Greene describes what he calls "the crucial gap between Dante and Petrarch" by arguing that Petrarch "could not imagine the companionable, progressively equalizing journey together of Dante and Virgil." Even as scholars like Anthony Grafton, Greene, and Mary

${ }^{2}$ For a discussion of Petrarch in the context of a textbook on the West, see Noble, 345. Studies both by medievalists and by early modernists have continued to make Petrarch's discovery of Cicero a pivotal moment of change from the medieval to the Renaissance or modern. See Minnis, 1984, 214, who locates in Petrarch's letter to Cicero a new attitude toward authority, while also noting that the medieval attitudes toward Solomon and David anticipate Petrarch's view. In his more extensive treatment of the topic, Minnis, 2008, 6, gives Petrarch the same prominent position. Schiffman similarly makes Petrarch's discovery the center of his story about the history of history. For a contrary view of the significance of the discovery, see Constable, 39: "Petrarch's famous rediscovery of the letters of Cicero ... was an event of personal rather than general significance."

${ }^{3}$ On the earlier accounts, see Ullman; and Garin, 1967.

${ }^{4}$ Mommsen, 236. Mommsen's footnote to this passage oddly refers to Burckhardt, who on the contrary claims that Dante "was and remained the man who first thrust antiquity into the foreground of national culture": Burckhardt, 137; see also 135-40. Indeed, Gombrich criticizes Burckhardt precisely for his inclusion of Dante. For Robert Black, Mommsen's reading of Familiarum rerum libri (Fam.) 6.2 avoids the tensions in Petrarch's account of antiquity, which Black sees as hybrid. Mommsen's contrast between Dante and Petrarch derives from his source, Simone, who identifies the emergence of a new historical self-consciousness in Petrarch, rejecting alternative proposals that located the Renaissance in Dante or Saint Francis and adducing a series of images of light and darkness that have become commonplaces in discussions of Renaissance self-consciousness.

${ }^{5}$ Greene, 29. Like Mommsen, Greene, 30, follows Simone's remark — which he translates from Simone's 1949 book — that "unlike the Humanists, the men of the Middle Ages never lost the sense of continuity which they imagined passing from people to people, according to an idea of which the translatio studii is a mythical realization." At the same time that Greene argues that Petrarch "was the first to notice that classical antiquity was very different from his own medieval world, and the first to consider antiquity more admirable," he 
Carruthers have shown that Petrarch's hermeneutics contains as much medieval allegorizing as Renaissance historicism, the consensus that has emerged, with apologies to T. S. Eliot, is that Dante and Petrarch divide the medieval and Renaissance worlds between them. ${ }^{6}$ While it is true that Petrarch's place as founder of Renaissance humanism has been challenged by scholars like Ron Witt, who locates Petrarch in the third generation of humanists, this has not accompanied a reassessment of Dante, who remains exiled from the idea of the Renaissance in a way that would have surprised Burckhardt. ${ }^{7}$ One wonders if one of the reasons the Italian Renaissance may seem lost, to appropriate the title of Christopher Celenza's book, is that this boundary between Dante and Petrarch is no longer contested. ${ }^{8}$

This essay revisits Petrarch's letters on his discovery of Cicero's letters to reconsider the distance between Dante and Petrarch in terms of their respective relationships to the past and the periodization of the medieval and Renaissance, or medieval and modern, that it entails. ${ }^{9}$ By examining this crucial moment, this

also acknowledges that "the Commedia was perhaps the first text in our millennium to possess something like a genuine historical self-consciousness. . . . No one before Dante could have described Virgil as hoarse from a long silence because no one was capable of measuring his own anachronistic distance from Virgil": Greene, 90, 17. Greene's study has continued to serve as a touchstone for later investigations of the issue, like Gouwens, 69; Barkan; de Grazia, 2007; and Schiffman, among others.

${ }^{6}$ For discussion of Petrarch's mix of humanist and medieval allegorical modes, see Greene, 94-95; and Carruthers, 163-69, 219. These views anticipate in some respects the arguments of Nagel and Wood, who want to break out of the debate about Renaissance anachronism by arguing that the Renaissance was not fully historicist, but included substitution theories as well. One could say that Nagel and Wood want to expand Petrarch's ambivalence to the whole Renaissance period, which would continue to place Petrarch in a primary, foundational position.

${ }^{7}$ Witt, 2000. In Witt's definition of humanism as the use of classicizing Latin, Dante has no real place, although Witt provides a valuable intellectual biography of him: ibid., 213-24.

${ }^{8}$ Celenza. It is significant in this regard that the last studies to argue for Dante as a humanist, whatever the value of their claims, are over sixty years old: see Montano; and Renaudet.

${ }^{9}$ I cannot address here the porous boundaries between the categories of Renaissance, early modern, and modern, but Petrarch and historicism play pivotal roles in accounts of each of these periods. For example, Findlen, 4: "Petrarch's profound sense of displacement from his own times and his fierce desire to recapture the glories of a neglected past lay at the heart of the cultural movement we know as the Renaissance." More broadly, Kelley, 1991, ix, asserts that "Renaissance humanism was — virtually by definition — present at the birth of the modern world." Frederic Jameson's classic account of postmodernism also relies on the historicism of modernity/modernism to define the later period: "it is hard to discuss 'postmodernism theory' in any general way without having recourse to the matter of historical deafness": Jameson, x-xi. In another story about found manuscripts, Greenblatt marks the modern by emphasizing not Petrarch's discovery of Cicero but Poggio's recovery of Lucretius. 
study contributes to the rethinking of issues of periodization that is currently underway in a variety of fields, such as art history, literary studies, and cultural studies. ${ }^{10}$ The narrative of Petrarch's privileged place has been questioned both by historians, such as Haskins, Chenu, Weiss, and Witt, who have identified rediscoveries of antiquity at earlier moments, and by literary scholars, such as Mazzotta, Wallace, Menocal, Wojciehowski, and Simpson, who have taken a metacritical approach, interrogating the critical investments involved in making Petrarch a foundational figure. ${ }^{11}$ This study takes a different path by reexamining the images that Petrarch uses to describe his discovery. It reveals that Petrarch initially conceives of this event - and the new historical perspective it putatively inaugurates - through Dante's characterization of Virgil. While critics have recognized Petrarch's echo of Dante in the letter (Familiarum rerum libri 24.3) since the early twentieth century, they have not examined its significance, because of long-standing ideas about Dante's relationship to the past (as in Greene's idea of "the companionable, progressively equalizing journey") and Petrarch's own claims that he had not read Dante in order to avoid imitating him (Fam.21.15). Both of these received ideas have been complicated by more recent research. Over the last thirty years American Dante criticism, particularly in the work of Teodolinda Barolini and Albert Ascoli, has developed a more multifaceted understanding of Dante's relationship to the classical past that has emphasized Dante's critical, not complacent, view of Virgil. ${ }^{12}$ The critical understanding of Petrarch's relationship with Dante has also been revised over the last few decades, culminating in a recent collection of essays edited by Zygmunt Baranski and Theodore Cachey that reveals how Petrarch strategically engages his precursor to marginalize him. ${ }^{13}$

This essay brings together these two critical developments to propose a different reading of the significance of Petrarch's letters to Cicero and the

${ }^{10}$ In art history, see Nagel and Wood, as well as the critique by Dempsey. In literary studies, see the work of de Grazia, 2007 and 2010; Wallace and Summit; and the cluster of articles in PMLA 127 (2012): 310-56. In cultural studies, see K. Davis. Nagel and Wood, 47 , note that historicism is the marker of the Renaissance, writing that "all parties seem to agree that the Italian Renaissance imposed the contrivances of cognitive distance on the fluid, associative models of historical time that prevailed in the Middle Ages. The only point in dispute is the relative value placed on cognitive distance."

${ }^{11}$ For studies that propose earlier dates for the rediscovery of antiquity, see Haskins; Chenu; Weiss; Witt, 2000; and the overview in Mazzocco. For metacritical analyses, see Mazzotta, 1993, 14-32; Menocal, 3-54; Wallace; Wojciehowski; and Simpson. Quillen also criticizes this received narrative, but her focus is on challenging the claim to authenticity. For a more recent discussion, see the summary in Zak, 15-21.

${ }^{12}$ See Barolini, 1984; and Ascoli, 2008, 301-405.

${ }^{13}$ See Petrarch and Dante: Anti-Dantism, Metaphysics, Tradition. 
historiography of the Renaissance, historicism, and the modern that it involves. By exploring how Petrarch constructs his encounter with Cicero, this study outlines Petrarch's complex framing of this moment in the Familiares and points to the analogous strategies Petrarch deploys in his construction of both Cicero and Laura. Despite being the author of what would serve as a kind of rhetorical handbook, or, better, thesaurus, for European poetry over several centuries, Petrarch's letters have rarely been treated as the literary artifacts that they are, even though Petrarch himself draws attention to his revisions of the letters' literary form in the first letter of the collection, Fam. 1.1, and critics, like Rossi and Billanovich, have shown that he changes the dates of his letters. ${ }^{14}$ While single letters in the Familiares, such as the account of his Ascent of Mt. Ventoux (Fam. 4.1), have been the subject of close analyses by scholars, the sophisticated construction of the letters to the ancients has been largely overlooked. ${ }^{15}$ By investigating the images and framing that Petrarch uses, this investigation will illuminate the conceptual ground for Petrarch's perception of the past.

\section{Framing THE Discovery of Cicero}

In the frame of the Familiares, Petrarch insists that the letters to the ancients will scandalize his readers, that he has a relationship to time that is different from his contemporaries', and that he has a new attitude toward authority. In Fam. 1.1 Petrarch highlights the importance of his discovery of Cicero's letters, explaining that Cicero's letters not only serve as the rhetorical model for the collection, but also gave him a new intimate understanding of the past, which he describes emphatically using the word offendere. ${ }^{16}$ Petrarch

${ }^{14}$ For discussions of Petrarch's use of the letter as literary form, see Struever, 3-34; Najemy, 26; Quillen, 106-47; Eden; and Mazzotta, 2009. For a comprehensive examination of the collection, see Antognini. On Petrarch's modifications to the dates of his letters, see Rossi, 1932; and Billanovich, 1947, 1-55.

${ }^{15}$ On Petrarch's letter on Mt. Ventoux (Fam. 4.1), see Durling; Ascoli, 2011, 21-58; and Billanovich, 1966. Also see the recent edition with commentary in Lokaj. An exception to the tendency to ignore the literary structures beyond the single letter is the analysis of Fam. 19 in Ascoli, 2011, 118-60. Although Cosenza gathers the letters in a single volume and provides a useful commentary, questions of structure and meaning are largely ignored.

${ }^{16}$ For the idea that Petrarch took his inspiration for his Familiares from his discovery, see Witt, 1982, 30; Lorch, 80; McLaughlin, 1995, 23; Mann, 12; Kinney, 80; Regn and Huss, 95. Although Petrarch's earlier recovery of Cicero's Pro Archia at Liége in 1333 (mentioned in Rerum senilium libri [Sen.] 16.1 and Fam. 13.6) is usually coupled with the discovery of Cicero's personal letters at Verona in 1345, it is this later discovery that Petrarch emphasizes in the Familiares. He does use the Pro Archia in the Coronation Oration. On the significance of the Pro Archia for humanism, see Reeve, 1996. 
writes: "In such difficulties [of life] Cicero revealed himself so weak that while I take pleasure in his style [stilo] I often feel offended by what he says [sententia offendar]. When I read his letters I feel as offended as I feel enticed [offensus]. Indeed, beside myself, in a fit of anger I wrote to him as if he were a friend living in my time with an intimacy that I consider proper because of my deep and immediate acquaintance with his thought. I thus reminded him of those things he had written that had offended [offenderer] me, forgetting, as it were, the gap of time." ${ }^{17}$ Petrarch distinguishes between Cicero's stilum, which he admires, and his sententia, which so "offends" him that he erases time by writing directly to Cicero in the first of a series of what become the letters to ancient authors. He warns his reader about these letters that occupy the end of the collection "so that the reader will not be filled with undue wonder when he comes upon them." ${ }^{18}$ Petrarch thus underlines the novelty not only of what he read, but also of his reaction to it. When Petrarch reminds the reader about these letters again at the end of the collection, he once again emphasizes their exceptional status as violations of the collection's chronological order: "I have arranged this work not according to subject but chronologically, with the exception of the last letters addressed to illustrious ancients, which I consciously brought together in one place because of their unity of character, and with the exception of the first letter, which, though written later, preceded its companions to serve as a preface; nearly all the others are arranged chronologically." 19

The play with multiple timeframes in this description, with its careful coordination and distinction between the temporality of reading and the time of composition, also characterizes the first letter of book 24 itself, where Petrarch addresses time's inescapability: "Thirty years ago — how time does fly! — and yet if I cast a glance backward to consider them all together, those thirty years seem as so many days, so many hours, but when I consider them singly, disentangling the mass of my labors, they seem so many centuries." 20 Petrarch suggests how one's perception of time depends on one's perspective, which he expresses through the dialectical relationship between part and whole that animates his collection of vernacular poems,

${ }^{17}$ Petrarch, 1975-85, 1:12-13. All translations are from this 1975-85 edition of Petrarch's letters by Aldo S. Bernardo. The Latin text is taken from Petrarch, 2004-09, which includes a helpful Italian translation by Ugo Dotti. In this passage, Bernardo's translation of sententia as "attitude" has been revised.

${ }^{18}$ Petrarch, 1975-85, 1:13 (Fam. 1.1).

${ }^{19}$ Ibid., 3:351 (Fam. 24.3).

${ }^{20}$ Ibid., 3:308. 
including its title, Rerum vulgarium fragmenta $(R v f) .{ }^{21}$ Considered as a continuum, time can seem insignificant, but taken individually each moment can appear to be a century. ${ }^{22}$ Petrarch continues to play with temporal perspective in this letter, comparing a man's life to that of an insect that lives a single day: "Let us divide times as we wish, let us multiply the number of years, let us invent names for the ages, yet man's entire life is as a single day, and that not a full summer day but a winter one, in which one dies in the morning, another at midday, another a little later, and another in the evening: one is young and blooming, another physically powerful, still another parched and wasted." ${ }^{, 23}$ Given Petrarch's play with the scales of time in this letter, it would be tempting to extend Petrarch's analogy to historical ages, but Petrarch's concern here is very much on a human scale.

Throughout the rest of Fam. 24.1, Petrarch insists that his relationship to time differs from that of his contemporaries, but not because he preferred the past, as he suggests elsewhere, but because he interpreted those works differently. ${ }^{24}$ Since his youth he has been able to "perceive a hidden meaning in the words unnoticed by my fellow students or even by my teacher, learned though he was in the elements of the arts. I would listen to Virgil proclaiming his divine words, "The beautiful first day of our lifetime flees wretched mortals, illnesses follow and sad old age, and the sufferings of a merciless death'; and elsewhere, 'Brief and unalterable is the span of life'; and again, 'But meanwhile time flies: and it flies never to return." ${ }^{25}$ In contrast to his contemporaries, Petrarch claims that he "would note not the verbal facility but the substance of the thought." 26

${ }^{21}$ For a discussion of this dialectic in the title, see Barolini, 2006, 193-94.

${ }^{22}$ On the ages of man, see J. A. Burrow, whose epigram comes from Petrarch's Secretum. For a concise history of macrohistorical perspectives, see Kelley, 2006.

${ }^{23}$ Petrarch, 1975-85, 3:313.

${ }^{24}$ The loci classici for Petrarch's hatred of his own time are the Letter to Posterity (Sen. 18.1), Triumphus Cupidinis 1.17, De Vita solitaria 1.8, and Sen. 3.9. His remarks in the Letter to Posterity are particularly relevant here because they show the same conjunction found in Fam. 1.1 between the wound (offensus) and forgetting (obliviscor): "I have dwelt single-mindedly on learning about antiquity, among other things because this age has always displeased me, so that, unless my love for my dear ones pulled me the other way, I always wished to have been born in any other age whatever, and to forget [oblivisci] this one, seeming always to graft myself in my mind onto other ages. I have therefore been charmed by the historians, though I was no less offended [offensus] by their disagreements; and, when in doubt, I followed the version toward which either the verisimilitude of the content or the authority of the writers pulled me": Petrarch, 1992, 2:673-74 (Sen. 18.1).

${ }^{25}$ Petrarch, 1975-85, 3:308-09.

${ }^{26}$ Ibid., 3:309. 
Petrarch would apply these ideas, moreover, to his own life, as his works and marginalia demonstrate. ${ }^{27}$ Petrarch frames this difference in terms of a conflict of authority that he explores in the next letter as well, emphasizing that this unique perspective gave rise to a new kind of authority that was based not on tradition but on his own experiences: "In this regard I have no need of poet or philosopher; I am my own witness and my own sufficient authority." 28 He continues: "I had previously believed learned men, now I believe myself, now I know what I once believed. For they learned merely by living, seeing, and observing, and proclaimed it to their followers as one warns travelers about an unsafe bridge." 29 Just as these authorities were only men, Petrarch can likewise be an authority not only for himself, but also potentially for others. To use another popular medieval image of the relationship between past and present, Petrarch does not stand on the shoulders of giants. ${ }^{30}$

Petrarch's idea of reading for moral instruction, of course, is not really as novel as he claims. In his Moral Epistle 108, Seneca had already used the same passage from Virgil's Georgics about time's flight that Petrarch cites to distinguish between how grammarians (or philologists) and philosophers interpret texts. Seneca argues that whereas the grammarian scrutinizes Virgil's use of the word fugit, the philosopher attends to the substance of the thought the verses express. ${ }^{31}$ Petrarch knew Seneca's letter well and in his

${ }^{27}$ Ibid.: "With what youthful zeal I plucked from them for several years before becoming familiar with other kinds of writers may be seen in my surviving works from that period, and especially in my marginal notations on certain passages whereby I would conjure up and precociously reflect upon my present and future state." For more on the significance of Petrarch's note-taking (and his reflections on this activity in the Secretum) for its influence on later humanists, see Schiffman.

${ }^{28}$ Petrarch, 1975-85, 3:312.

${ }^{29} \mathrm{Ibid}$., 3:313. He writes, "Between me and my contemporaries, and even my elders, was this difference: to them the journey seemed certain and endless, to me it seemed in fact short and doubtful. In frequent conversations and youthful disputes concerning this, my elders' authority prevailed, making me almost suspected of madness": ibid., 3:311. Petrarch notes that he has changed even in the course of writing this letter: ibid., 3:312.

${ }^{30} \mathrm{On}$ this medieval image, which is attributed by John of Salisbury (Metalogicon 3.4) to Bernard of Chartres, see Merton.

${ }^{31}$ Seneca advocates for a return to this philosophical or moral mode of reading because, as he claims just before the discussion of Virgil, "what was philosophy has become philology" ("quae philosophia fuit facta philologia est": Seneca, 1925, 3:244 [Epistles 108.23]; my translation), that is, an attention to the words instead of the ideas. Nietzsche transforms Seneca's phrase at the close of his "Homer and Classical Philology." For discussions of Nietzsche's use of the phrase, see Porter, 35-36; and Capodivacca. 
Ambrosian Virgil he transcribes the relevant passages from it next to the pertinent verses of the Georgics. ${ }^{32}$ Grafton has shown that Justus Lipsius uses this same passage from Seneca to challenge Scaliger's philological historicism and Petrarch's point here seems to be similar. ${ }^{33}$ Petrarch's new hermeneutics is less historicist than it is philosophical. Such a view would be very much in keeping with what are usually characterized as medieval interpretive modes, and several scholars, such as Grafton and Greene, have noted Petrarch's mix of the allegorical and historical.

Petrarch's description of the reception of his discovery in the next letter, Fam. 24.2, dated 13 May 1351, continues to distinguish his perception of the past from his contemporaries' and to reinforce his claim that the letters to the ancients will cause his readers to marvel. Petrarch recounts, or stages, the scandal the letter produced by describing a conversation about Cicero among a group of friends outside Vicenza. ${ }^{34}$ He writes:

It happened that while I expressed almost unreserved admiration for Cicero, a man I loved and honored above all others, and amazement too at his golden eloquence and heavenly genius, I had no praise for his weak character and his inconstancy, which I had discovered from various bits of evidence. When I noticed the astonishment of all present at my novel opinion, and especially that old man whose name escapes me but whose face I remember well since he is a fellow townsman of yours and a venerable scholar, it seemed an opportune time for me to fetch from its box the manuscript containing my letters. 35

Although the logic of this scene would seem to dictate that Petrarch should have Cicero's letters fetched as evidence, he has his own letters brought out instead. This choice suggests that Petrarch's reaction to the discovery is just as important as the letters he discovered, which puts

32"Life's fairest days are ever the first to flee for hapless mortals; on creep diseases, and sad age, and suffering; and stern death's ruthlessness sweeps away its prey": Virgil, 1916, 158-59 (Georgics 3.66-68); and "fugit inreparabile tempus" ("time flies never to return"): ibid., 174 (Georgics 3.284). In Georgics 3, Petrarch records Seneca's remarks on time (108.24-29) for vv. 66-68, and another Senecan passage (108.23-24) for vv. 284-85. Petrarch also quotes or cites from Seneca's letter in Fam. 1.3.3, 23.2, and 24.1.5, as well as Sen. 4.5. The other Virgilian passage that Petrarch quotes is from Aeneid 10.467, which does not appear in Seneca's letters. Seneca's first letter is also on the flight of time.

${ }^{33}$ For a discussion of this Senecan passage, see Grafton, 1985, 640-41.

${ }^{34}$ The same interplay between reception and text occurs in Petrarch's recounting of his tale of Griselda in Sen. 17.4.

${ }^{35}$ Petrarch, 1975-85, 3:314. 
Petrarch's letters on the same plane as Cicero's. ${ }^{36}$ Just as Cicero's sententia scandalizes Petrarch, Petrarch's new sententia about Cicero causes its own scandal.

Petrarch underlines his new critical relationship to Cicero by contrasting it with the old man who persists in thinking that Cicero is a god. ${ }^{37}$ Petrarch associates his new way with reason as opposed to an old mode based on authority:

When it was brought in, it provoked even more discussion, for along with many letters to my contemporaries, a few are addressed to illustrious ancients for the sake of variety and as a diversion from my labors; and thus, an unsuspecting reader would be amazed at finding such outstanding and honorable names mingled with those of contemporaries. Two are addressed to Cicero: one expresses reservations about his character, the other praises his genius. When you had read them to the attentive onlookers, a friendly argument ensued, in which some agreed with me that Cicero deserved the criticism. Only the old gentleman became more obstinate in his opposition; so taken was he with Cicero's fame and so filled with love for him that he preferred to applaud even his errors and to accept his vices together with his virtues rather than condemn anything in a man so worthy of praise. The old man held the same deep-seated opinion of Cicero that I recall having as a boy, and even at his age was incapable of entertaining the thought that if Cicero were a man, it followed that in some things, perhaps not in many, he must have erred. ${ }^{38}$

Petrarch dismisses the inherited view of Cicero that he had believed as a boy and certain obstinate old men continue to hold, setting that old view against the reason of his new view of Cicero as a historical, fallible man. By making Cicero into a fallible man, and arguing that ancient authors had "learned merely by living, seeing, and observing, and proclaimed it to their followers as one warns travelers about an unsafe bridge," Petrarch prepares conceptual space so that he can become an authority. ${ }^{39}$

${ }^{36}$ This story would exemplify why the discovered manuscript is one of the great narrative topoi, from Dante's Vita nuova to Ariosto and Cervantes. On the authenticating function of the found-manuscript topos, in which the work acquires its real meaning only when retranscribed, see Grafton, 1990, 58.

${ }^{37}$ Petrarch's attack here is part of a long tradition that continues through Erasmus's Ciceronianus. For a convenient selection of earlier debates, see DellaNeva.

${ }^{38}$ Petrarch, 1975-85, 3:314-15.

${ }^{39}$ Ibid., 3:313 (Fam. 24.1). Ibid., 3:314-15, notes that readers will be amazed to see ancients mixed with moderns, which problematizes Mommsen's claim that Petrarch kept them separated, but also see Dante who first accomplishes this union. Petrarch mourns their fates as pagans and grieves over their faults: Petrarch, 1975-85, 3:316. 


\section{Shades of Dante's Virgil in PETRARCh'S CiCERo}

Having established his putatively novel hermeneutics in Fam. 24.1 and his association with reason against old authorities in Fam. 24.2, Petrarch has constructed the frame that will give his discovery of Cicero's manuscript its meaning. ${ }^{40}$ Reading Cicero's letters, Petrarch is surprised to find not a sage philosopher, but a fickle and changeable political operator: "While for some time I had known the kind of teacher [preceptor] you were for others, now finally I realize what kind of guide you were for yourself." ${ }^{\prime 1}$ Petrarch laments that the anxieties and impulsiveness he finds in Cicero's letters do not suit Cicero's age or profession: "O wretched and distressed spirit, or to use your own words, O rash [preceps] and ill-fated elder." ${ }^{\text {42 }}$ Disappointed that his preceptor was in fact preceps, Petrarch expresses his newly complex vision of Cicero with the image of the night traveler bearing a lantern: "Alas, forgetful of brotherly suggestions and so many of your own salutary precepts, like a traveler by night, bearing a light in the darkness, to those who followed you you showed the way on which you yourself had quite miserably fallen." Cicero bore the light of philosophical truth but his letters reveal that he was

${ }^{40}$ Billanovich argues that the conventional account whereby Petrarch found the codex himself in the chapter library of Verona seems unlikely, since even Petrarch would have had difficulty gaining access to the collection. He proposes that Petrarch acquired the letters through the intervention of Guglielmo da Pastrengo: see Billanovich, 1990, 260; and Billanovich, 1997, 140-41. Although neither the original manuscript nor Petrarch's copy survive, the codex likely contained Cicero's Ad Atticum, Ad Brutum, Ad Quintum fratrem, as well as the pseudo-Ciceronian letter to Octavian, each of which he quotes or cites in his first letter about the discovery (Fam. 24.3). Although the letter to Octavian is often omitted from descriptions of Petrarch's discoveries, this misattributed work seems to have a major impact on Petrarch, to judge by the density of references to it in Fam. 24.3.

${ }^{41}$ Petrarch's interpretation of Cicero's political activities is quite different from what one finds in some earlier figures, like Brunetto Latini, whose idea of Cicero seems to have influenced Dante's own understanding of him in the Convivio. For discussion, see C. Davis, 166-97. Silvia Rizzo in Feo, 1991, 133-35, notes that Fam. 24.3 was a locus of later debates on active participation in civil life; Poliziano, for example, also pens a reply in defense of Cicero in the margins of his copy of the letters.

${ }^{42}$ Petrarch continues, "Why did you choose to become involved in so many quarrels and utterly useless feuds? Why did you forsake that peaceful ease so befitting a man of your years, your profession, and your fate?": Petrarch, 1975-85, 3:317 (Fam. 24.3). The quotation of Cicero's own words comes from the pseudo-Ciceronian Letter to Octavian 6: see Cicero, 2002, 350 .

${ }^{43}$ Petrarch, 2004-09, 5:3496: "Heu et fraterni consilii immemor et tuorum tot salubrium preceptorum, ceu nocturnus viator lumen in tenebris gestans, ostendisti secuturis callem, in qua ipse satis miserabiliter lapsus es." Bernardo's translation in Petrarch, 1975-85, has been revised here. 
not illuminated by them and was carried off to a death unworthy of a philosopher.

Commenting on this image of the traveler in his recent The Birth of the Past, Schiffman writes: "One wonders - as perhaps Petrarch intended from whom he borrowed this striking image. (And what greater delight than to beguile readers into thinking his own words those of an ancient!) ${ }^{\text {"44 }}$ The most likely source for Petrarch's image, however, is not a classical author, as Schiffman suspects, but a modern vernacular one, Dante. As Rossi was the first to note in a 1904 article ${ }^{45}$ the image of the figure who carries a light that illuminates the path for those that follow echoes Statius's description of Virgil in Purgatorio 22: "You did as one who walks at night, who carries the light behind him and does not help himself, but instructs the persons coming after, when you said: 'The age begins anew; justice returns and the first human time, and a new offspring comes down from Heaven." "46

To describe Statius's conversion through reading Virgil's fourth eclogue, Dante has Statius adopt the poetics of light that radiates from Plato's cave into the Gospel of John and the works of Augustine, and join it to the ancient poet's own image of the footsteps to figure succession at the end of the Thebaid: "Live, I pray; and essay not the divine Aeneid, but ever follow her footsteps from afar in adoration." ${ }^{, 47}$ The image of the poet bearing a lantern also contrasts with the earlier portrait in Inferno 28 of Bertran de Born, who bears his own head like a lantern to demonstrate the logic of the contrapasso. ${ }^{48}$ Implied in this disparity between Virgil and Bertran de Born is the difference between the limbo of the classical poets, whose nobile castello illuminates hell and whose penalty is privation, and the punishments of hell proper. The more natural relationship between poetic body and lamp in

${ }^{44}$ Schiffman, 157.

${ }^{45}$ Rossi, 1930.

${ }^{46}$ Dante, 2:365-66 (Purg. 22.67-72): "Facesti come quei che va di notte, / che porta il lume dietro e sé non giova, / ma dopo sé fa le persone dotte, / quando dicesti: 'Secol si rinova; / torna giustizia e primo tempo umano, / e progenie scende da ciel nova."”

${ }^{47}$ Statius, 309 (Thebaid 12.816-17). For a dense discussion of light metaphors that begins with Parmenides, see Blumenberg. Blumenberg's metaphorology shares something with Rorty, 12: "It is pictures rather than propositions, metaphors rather than statements, which determine most of our philosophical convictions."

48"I surely saw, and it seems I still see, a torso without a head walking like the others of the sorry flock; and his severed head he was holding up by the hair, dangling it from his hand like a lantern; and the head was gazing at us, saying: 'Oh me!' Of himself he made a lamp for himself, and they were two in one and one in two; how that can be, he knows who so disposes": Dante, 1:439 (Inf. 28.118-26). For a reading of Bertran as "a grotesque inversion of Vergil," see Barolini, 1984, 172. For more on the category of the fallible author, see Minnis, 2008. 
Dante's Virgil, however, also reflects a critique, since Dante uses it to distinguish between the fallible author and his salvific text. ${ }^{49}$

Statius's image of the poet who illuminates the path but is not illuminated expresses in concentrated form the complexity of Dante's relationship to the classical past, particularly with regard to Virgil. Whereas critics have often emphasized Dante's claims of continuity and companionship that he dramatizes in his encounter with the classical poets in Inferno 4, Dante makes the critical nature of this relationship quite clear, beginning with Virgil's failure at the Walls of Dis, which the Pilgrim pointedly recalls to Virgil later in the poem when he addresses him: "Master, you who overcome all things, save the hard demons who came out against us at the gate." ${ }^{~}$ As the work of Barolini in particular has shown, one of the main narrative threads of Dante's overdetermined poem is his concentrated effort to critique and surpass Virgil, which is correlated with developing a new intimacy with him. ${ }^{51}$ Like Dante, Petrarch uses the image to express a complex relationship toward the classical past, represented by Cicero instead of Virgil, whose achievements he admires but whose limitations he also emphasizes.

The Dantean derivation of this image is reinforced by Petrarch's explicit, which once again uses Dante's characterization of Virgil in the Commedia to describe Cicero. Petrarch signs the letter "in the year 1345 from the birth of that Lord whom you never knew." 52 This echo of Dante's address to Virgil, "by that God whom you did not know," suggests a connection between the Statius episode and Inferno 1 that one finds in Dante's Trecento commentators, like Boccaccio and Benvenuto da Imola, who use these passages to gloss each other, since Virgil's lack of illumination is related to his lack of faith. ${ }^{53}$ Petrarch's attention to Cicero's lack of faith emphasizes, as

${ }^{49}$ The final stage in this series of poet-lantern relations may occur in Paradiso 2, where Beatrice describes an experiment involving mirrors and candles in which, according to some readings, the implication may be that Dante's body is transparent. Putting the theological implications of this possibility aside, the idea of the light radiating through the poet Dante would be a remarkable image of Dante as prophet and scribe that would balance those of Bertran and Virgil. For discussion of whether Dante is transparent or not in this experiment, see Moevs, 111-19.

${ }^{50}$ Dante, 1:221 (Inf. 14.43-45).

${ }^{51}$ For the complexities of Dante's engagement with Virgil, in addition to Barolini, 1984, see the studies collected in Jacoff and Schnapp.

${ }^{52}$ Petrarch, 1975-85, 3:318.

${ }^{53}$ Dante, 1:33 (Inf. 1.131): "per quello Dio che tu non conoscesti." Two of Petrarch's correspondents, Boccaccio and Benvenuto da Imola, also connect Virgil's prophecy of the Veltro in Inferno 1 to his fourth eclogue. 
Witt has noted, the theological divide between them, which is very much in keeping with the meaning of Dante's episode, and Petrarch returns to this topic of Cicero's lack of faith elsewhere in reference to his discovery of Cicero and uses Virgil as an explicit parallel. ${ }^{54}$

The combination of these two Dantean quotations in Petrarch's letter suggests that Petrarch's model for his critical view of Cicero is Dante, whose supposedly uncritical relationship to the past is often used in contrast to Petrarch's. Indeed, critics have been remarkably resistant to examining these Dantean echoes in Petrarch's letter. ${ }^{55}$ Two years after Rossi first proposed that Dante was Petrarch's likely source, Carrara rebuffed the idea, suggesting instead a passage from (now pseudo-)Augustine's De symbolo that had been viewed as one of the potential sources for Dante's passage at least since Tommaseo in $1837 .{ }^{56}$ More recently, critics seem to have accepted the Dantean source of the allusion, but even scholars, like Dotti and Feo, who have recognized both of these Dantean quotations in the letter, have not investigated their significance. ${ }^{57}$

${ }^{54}$ Witt, 2000, 279-80. For similar remarks about the problem of classical authors' lack of faith, see Petrarch, 1990, 463-67 (De vita solitaria 1); Petrarch, 2002, 42 (De otio religioso); and Petrarch, 2003, 272-75 and 286-93 (De ignorantia, secc. 58 and 73-80).

${ }^{55}$ For mentions of the Dantean connection without further analysis, see Cosenza, 13-14; Cook; Spitzer, 123; and Feo, 2006, 36-37. Rotondi, 131, points to a saying attributed to Plato in the Liber philosophorum moralium antiquorum, but his suggestion has not been followed by anyone to my knowledge

${ }^{56}$ The Augustinian passage is, "O Jews, you carry in your hands the torch of the law, and while you light the way for others, you are yourselves shrouded in darkness": Augustine, 1845,664 . Tommaseo had included the passage in his 1837 commentary on Dante along with one from the Confessions, which Pietro Alighieri's commentary had also cited. Nolhac, 1:257n2, prefers Augustine. Although the two quotations from Dante in Fam. 24.3 suggest that Dante is the more likely source, the passage from De symbolo suggests the parallel between pagan and Hebrew authors that was prevalent in medieval exegesis; see Minnis, 1984, 115. Just as the Hebrew Bible was fulfilled by Christian revelation, Virgil prepared the way for the joining of poetry and truth that occurs in Statius, and Dante himself. On the issue of typology, see Charity; Freccero; Ohly; and Biddick.

${ }^{57}$ In the Dante commentary tradition, Bosco and Reggio are the first to note the parallel to Petrarch, on the strength of Rossi, 1930; and Carrara, but the more recent commentary of Chiavacci Leonardi once again maintains that Petrarch must have taken the image not from Dante but from the presumed common source of Augustine. For these and other commentaries, see the Dartmouth Dante Project: http://dante.dartmouth.edu. For a reading of this Dantean passage as connected to Christian imagery of the Pentecost, see Martinez, 1995. Baglio, 93, notes it as part of a survey of Dante's presence in Petrarch's Latin works. Pulsoni argues that this Dantean quotation is a sign that Petrarch had read Dante before Boccaccio gave him a copy of the Commedia in the early 1350s. In Petrarch, 2004-09, 5:3497n5, Dotti notes the Dantean source as a possibility along with Augustine and adds a passage from Ennius quoted in Cicero De officiis 1.16.51, perhaps on the strength of 
That Petrarch might quote Dante here is something of an embarrassment for several related reasons. Petrarch's quotation of Dante calls into question Petrarch's claim about not having read Dante in order to avoid imitating him in a letter to Boccaccio (Fam. 21.15) - a claim that scholars have increasingly contested - and it challenges the novelty of Petrarch's historical perspective. ${ }^{58}$ In his letter to Boccaccio, Petrarch justifies not possessing a copy of the Commedia by explaining that at the time he feared "becoming an unwilling or unconscious imitator" of Dante, so he avoided reading him. ${ }^{59} \mathrm{He}$ then emphatically asserts: "This one thing I do wish to make clear, for if any of my vernacular writings resembles, or is identical to, anything of his or anyone else's, it cannot be attributed to theft or imitation, which I have avoided like reefs, especially in vernacular works, but to pure chance or similarity of mind, as Tullius calls it, which caused me unwitting to follow in another's footsteps. If you ever believe me about anything, believe me now; nothing can be more true. ${ }^{{ }^{60}}$ In two later letters (Fam. 22.2 and 23.19) that, like Fam. 21.15, are addressed to Boccaccio, Petrarch continues to develop his theory of imitation; in Fam. 23.19, he distinguishes between poets, who borrow elements of style and ideas that they conceal, and mere apes, whose use of actual words is "glaring." Although these letters explicitly address his accidental imitation of Ovid and Virgil in his Buccolicum carmen, Dante does not seem to be far from

Moore, who, according to Singleton's commentary, is the first the Ciceronian source for Ennius; see Moore and Singleton in the Dartmouth Dante Project. This image from Ennius is not convincing, as Rossi, 1930, had argued earlier. Also see Feo, 2006, 36-37.

${ }^{58}$ For recent discussions of Petrarch's debts to Dante, see Petrarch and Dante: Anti-Dantism, Metaphysics, Tradition. Others have seen the evidence of Petrarch's knowledge of Dante as grounds for revisiting the chronology of Petrarch's knowledge of Dante. See Pulsoni; and, for the argument that Petrarch's encounter with Dante may have occurred in Genoa before the move to Provence, see Foresti, 6-7.

${ }^{59}$ Petrarch, 1975-85, 3:204. Given Petrarch's own insistence on carefully attending to his sources and changing his text to avoid imitation, as in his letters to Boccaccio about the Bucolicum carmen, he clearly understands that the only way to avoid imitation is to know the text well enough to prevent it.

${ }^{60}$ At least since Bosco, critics have discussed whether Petrarch quotes Dante's episode of Ulysses in the letter. Petrarch's Ciceronian quotation here is quite odd, since the passage he refers to (De oratore 2.36) - and quotes again in Fam. 22.2 - actually claims that such an excuse is foolish. Cicero's point is that imitation due to "pure chance or similarity of mind" is a laughable excuse; it is far more likely that these similarities are the result of having read those previous texts. Petrarch cites the same Ciceronian passage in Petrarch, 1934, 152 (Rerum memorandum libri 3.66.5). Petrarch's earlier reference to Quintilian's relationship with Seneca as an analogue to his own with Dante is similarly ambiguous, since the passage in Quintilian is also a critical problem for classicists: see Laureys.

${ }^{61}$ Petrarch, 1975-85, 3:302. 
Petrarch's mind. Petrarch's borrowing from Dante in the letter to Cicero is remarkable, then, because Petrarch insists on the letter's novelty - the new hermeneutics of 24.1 and his reason opposed to old authorities in $24.2-$ and insists earlier in the collection that he avoided reading Dante to escape his influence (Fam. 21.15). ${ }^{62}$

Less important than catching Petrarch in a lie about his debts to Dante, or reigniting what Ferguson once condescendingly referred to as "the revolt of the medievalists," is that Petrarch's crucial encounter with Cicero, around which the whole of the Familiares is structured, occurs through Dante. ${ }^{63}$ When Dante claims in Inferno 1 that Virgil was "one who seemed faint from a long silence," he is not suggesting that Virgil was unread in the medieval period but that none had understood him as well as Dante does. ${ }^{64}$ What is interesting here is not primarily the question of precedence, but the perhaps more incredible fact of the way Dante's vernacular text informs Petrarch's Latin humanism. Instead of pushing back the boundary of the Renaissance by positing some set of criteria that would define a new historical or critical relationship to the past, what Petrarch's borrowing shows is that he understood Dante's innovation and used it to structure his own expression of his relationship to antiquity.

In his Unearthing the Past, Leonard Barkan follows Foucault when he notes the importance of considering "the conditions that made discovery possible and gave it meanings" in order to explain why certain remarkable statues that had reemerged, like the Torso Belvedere, were not celebrated in the same way that the Laocoon was. ${ }^{65}$ Likewise, the novelty of Petrarch's relationship to the past did not simply appear off of the library's shelves. As Eugenio Garin puts it, humanism is characterized not by "the discovery of new classical texts," but "its attitude to the civilization of the past," which "consists rather in a well marked historical consciousness." ${ }^{166}$ By recycling the image Dante has Statius use to distinguish between the condemned author and salvific text in order to express his new relationship with Cicero,

${ }^{62}$ It is revealing that when Petrarch characterizes what Dante means to Boccaccio he uses the same image: "primus studiorum dux et prima fax" ("the first guide and first light of your studies") in Petrarch, 2004-09, 5:3070 (Fam. 21.15). The implication seems to be that Boccaccio's Dante is like Petrarch's Cicero, destined to fail; see Martinez, 2010.

${ }^{63}$ Ferguson, 330.

${ }^{64}$ Dante, 1:28 (Inferno 1.63): "chi per lungo silenzio parea fioco." The translation of this passage is mine.

${ }^{65}$ Barkan, 17. Barkan is recasting Foucault's idea of the episteme, which is often compared to Kuhn's idea of the paradigm; for a discussion of this connection, see Agamben. For another perspective on this problem of what constitutes discovery, see Reeve, 1991, 115-18.

${ }^{66}$ Garin, 1965, 11, 14. 
Petrarch reveals how Dante had shaped his perception of the past. ${ }^{67}$ In other words, Dante created the conditions of possibility that allowed for the emergence of Petrarch's new perspective, since the language that Petrarch uses to express the disjunction or discontinuity is Dante's own.

Petrarch's worries about imitation in those two letters to Boccaccio (Fam. 22.2 and 23.19) would lend themselves to an interpretation of this relationship in terms of the so-called anxiety of influence, but the problem is that Dante is hidden in plain sight, as Ascoli has observed of another of Petrarch's borrowings from Dante. ${ }^{68}$ Another interpretation could take this passage as a conscious invocation of Dante that might be part of the same double move that one finds in Dante's Commedia, whereby a critique of the classical past is also an engagement with modern literary culture. Just as Dante's use of Statius to show Virgil's limits serves as the classical parallel to Dante's own relationship with Cavalcanti, already recounted in similar terms in the Vita nuova and then continued in the Commedia, Petrarch's use of Cicero may also have a modern component in his relationship with Dante. ${ }^{69}$ While this idea that Petrarch is using the classical past to reflect on his own place in literary history is intriguing, more interesting than adding to the catalogue of quotations would be that Petrarch, at least, sees Dante as a predecessor for his own idea of history, whose novelty he emphasizes. ${ }^{70}$

Petrarch's extensive borrowing from the Statius-Virgil episode suggests that he understood Dante's critical relationship to antiquity, and he may well have recognized that its inclusion is one of the fundamental novelties of Dante's poem. Dozens of otherworld journeys before Dante put clerics in hell, but none had classical figures. As Alison Morgan notes in her comparative study of otherworld visions, arguing against Curtius's claim that Dante's inclusion of contemporary figures was the novelty: "the Comedy contains a lesser, not a greater, proportion of contemporary characters than the visions, and that Dante's originality lies not here but rather in the

${ }^{67}$ See Greene, 36, who poses the literary-historical question of his inquiry as how was it possible for Petrarch to move from seeing these figures as authorities to seeing them as friends? Minnis, 1984, provides part of the answer in the emerging emphasis on the authors of the Bible as human and fallible.

${ }^{68}$ Ascoli, 2009, 135. For the idea of the anxiety of influence, see Bloom. For the application of this idea to Petrarch's relationship to Dante, see Pasquini.

${ }^{69}$ Dante will recuperate both Virgil and Cavlacanti in the earthly paradise, as he surpasses both of them to claim the title of God's scribe. There are several intersections between Statius and Cavalcanti in the Comedy that would repay further attention, but are beyond the scope of the present inquiry.

${ }^{70}$ See Barolini, 2009a. 
inclusion of classical figures, who are totally unrepresented in the earlier medieval texts." ${ }^{71}$ Dante's treatment of Virgil is exemplary of this new attitude.

Dante's relationship with Virgil, moreover, has all the hallmarks of Petrarch's relationship with Cicero: it has a historical basis, involves an imagined intimacy, and entails a critical relationship toward the classical figure. ${ }^{72}$ Dante establishes a critical relationship with Virgil that is based on both a historical understanding of the poet that dispenses with the legendary elements that developed in the medieval period (Virgil explains, "I was born sub Iulio, though it was late, and I lived in Rome under the good Augustus in the time of the false and lying gods") and an imagined intimacy with him, since over the course of the poem Virgil is not only the Pilgrim's guide and teacher, but also figured as his mother and father at the moment of his disappearance. ${ }^{73}$ Even, or especially, against the allegorical background of the first canto, Dante insists on representing Virgil as a real person. ${ }^{74}$ A comparison with Brunetto Latini's treatment of Ovid in his Tesoretto brings the novelty of Dante's treatment into relief. Brunetto treats Ovid as an authoritative magister who, in keeping with the other allegorical figures such as Nature that populate Brunetto's poem, helps to put the poet-traveler back on the right path: "But Ovid through artistry / Gave me the mastery, / So that I found the way / From which I had strayed." ${ }^{\prime 5}$ The complexity of Dante's treatment of Virgil, then, provides the paradigm or model for Petrarch's multifaceted relationship with Cicero.

Dante's account of the Statius-Virgil encounter also informs the final book of Petrarch's Africa, which often features as another major piece of textual evidence for Petrarch's new attitude toward the

${ }^{71}$ Morgan, 57.

${ }^{72}$ Dante is not the first to articulate a critical relationship to Virgil, of course. John of Salisbury also makes critical remarks on Virgil in his Policraticus 8.25 (in Ziolkowski and Putnam, 549), but unlike Dante, John gives Virgil no light at all, and it is in the complex nexus of praise and blame that Petrarch most crucially follows Dante's conception.

${ }^{73}$ Dante, 1:30 (Inferno 1.70-72). The fact that Dante gets the chronology of Virgil's birth wrong, since he was not in fact born "sub Julio," is beside the point. For the Virgilian legends in the medieval period, see Comparetti; and, more recently, Ziolkowski and Putnam.

${ }^{74}$ For the importance of Dante's representation of Virgil as the historical poet as part of Dante's figuralist approach to representation, see Auerbach, 67-71. It is interesting in this connection that Panofsky, 100, singles out the treatment of Virgil in the visual arts as distinguishing medieval and Renaissance.

${ }^{75}$ Latini, 119 (Tesoretto 2390-94). 
past. ${ }^{76}$ Critics have shown how Petrarch uses elements from Statius's encounter with Virgil for Ennius's dream of Homer with its prostration and failed embrace, but the whole book is replete with Dantean echoes. ${ }^{77}$ The following verses are most often cited as exemplary of Petrarch's new vision of antiquity:

But perhaps, as I hope and pray, if you survive long after me,

Better centuries will ensue for you. This Lethean sleep

Will not last for all time! Perhaps once these shadows

Will have been removed, our descendants will return

To their original pure brilliance. ${ }^{78}$

Critics have often identified this passage as marking "the moment at which the metaphor of light and darkness lost its original religious value and came to have a literary connotation."79 In the second volume of his Renaissance in Italy, entitled The Revival of Learning, Symonds uses the verses as the epigraph and motto that he regards as "a prophecy of the Renaissance." ${ }^{\prime 00}$ In his Renaissance and Renascences in Western Art, Panofsky considers these verses as conveying Petrarch's "Copernican discovery" of antiquity. He comments that "in transferring to the state of intellectual culture precisely those terms which the theologians, the Church Fathers and Holy Writ itself had applied to the state of the soul (lux and sol as opposed to nox and tenebrae, 'wakefulness' as opposed to 'slumber,' 'seeing' as opposed to 'blindness'), and then maintaining that the Roman pagans had been in the light whereas the Christians had walked in

${ }^{76}$ The other evidence is usually Letter to Posterity (Sen. 18.1) and Epystola metrica 3.33. The claim that Petrarch aims at avoiding anachronism in the Africa has been overstated by studies like Regn, S81-82, which sees Petrarch as getting rid of the hybridity between the classical and Christian that one finds in Dante. That Petrarch would strive for such a distinction is not surprising, since Mago's lament (the only part of the Africa to circulate) was criticized for giving Christian ideas to a pagan character. In a letter to Boccaccio, Petrarch argues that there is no anachronism because the sentiment could just as easily be expressed by a pagan as a Christian: see Petrarch, 1975-85, 1:45 (Sen. 2.1), which is dated to 1363. Whereas Mommsen, Panofsky, and Regn all see Petrarch as reducing the Christian element, Witt, 2000, sees him as emphasizing it.

${ }^{77}$ Velli notes the Dantean connection; as does Galligan. Also see Brownlee, 479-83. Petrarch may also evoke the purgatorial encounter in Bucolicum carmen 10, Laurea occidens, which is another of Petrarch's major forays into literary history: see Baglio, 101n32.

${ }^{78}$ Bernardo, 1974, 150 (L'Africa 9.453-57); Petrarch, 1926, 278: "At tibi fortassis, si — quod mens sperat et optat — / Es post me victura diu, meliora supersunt / Secula: non omnes veniet Letheus in annos / Iste sopor! Poterunt discussis forte tenebris / Ad purum priscumque iubar remeare nepotes."

${ }^{79}$ Simone quoted in Mommsen, 227. Also see Gombrich; and Wojciehowski, 38.

${ }^{80}$ Symonds, $87 \mathrm{n} 1$. 
darkness, he revolutionized the interpretation of history no less radically than Copernicus, two hundred years later, was to revolutionize the interpretation of the physical universe." ${ }^{\prime 1}$

The claim that this "original pure brilliance" refers to antiquity is not universal, however. Bernardo, for example, claims that these verses were added after Robert of Anjou's death (1343) and that it is his death that brings on the new darkness. ${ }^{82}$ Bernardo's historicist reading of these lines has not found much traction, however. Thomas Greene adopts Panofsky's image of Petrarch's "Copernican leap," contrasting Dante's image of antiquity in limbo with these verses of the Africa. ${ }^{83}$ Instead of "the companionable, progressively equalizing journey together of Dante and Virgil," he argues that "the ending of the Africa reveals a different fantasized itinerary, wherein the future writer will walk back against time, free and guiltless, into the luminous fields of antiquity. ${ }^{\prime 84}$ Having just quoted Inferno 4 on the previous page, it is surprising that Greene does not mention the connection between those luminous fields and Dante's limbo, which also grants light to classical antiquity. Just as the image of the traveler who bears light for his followers simultaneously aims to honor a predecessor while also acknowledging his limitations, limbo shines forth in the darkness. As discussed above, the relationship of lantern to poet distinguishes Bertran de Born from Virgil and the punishments of hell from the privations of limbo. Indeed, the whole point of Dante's image, in contrast to contemporary configurations of Virgil that one finds in John of Salisbury, is that Virgil does bear a light, which reflects the light of classical culture whose very presence in limbo is Dante's heterodox innovation. ${ }^{85}$

\section{Reframing Dante and The Traces of CICERO AND LAURA}

In his second letter to Cicero (Fam. 24.4), dated six months later, 19 December 1345, Petrarch aims to avoid Dante by adducing a classical,

${ }^{81}$ Panofsky, 10-11. Although Panofsky recognizes that Petrarch was a Christian (who certainly did not believe, as Panofsky claims, that Christians were in the darkness), what distinguishes the Renaissance from the previous renascences for him is the emergence of the idea of antiquity.

${ }^{82}$ Bernardo, 1962, 45-46.

${ }^{83}$ Greene, 35. For similar remarks about Petrarch reversing a Christian distinction, see Burke, 21; Stierle, 64; and Jauss, 341-42.

${ }^{84}$ Greene, 29.

${ }^{85} \mathrm{John}$ of Salisbury also makes critical remarks on Virgil in his Policraticus 8.25 (in Ziolkowski and Putnam, 549). For the heterodoxy of Dante's inclusion of pagans in limbo, see Iannucci. 
indeed Ciceronian, source for his critique of Cicero, but he also reinforces the implied parallel between Dante's Virgil and his own Cicero. Apologizing for his intemperate earlier letter, Petrarch notes that his distinction between Cicero's life and his genius or language follows Cicero's own complex attitude toward Epicurus, whose life Cicero had praised, even as he had criticized his thought. ${ }^{86}$ Petrarch's letter then takes a surprising turn. Petrarch claims that while Cicero was his leader $(d u x)$ in prose, he had another master in poetry, Virgil. ${ }^{87}$ Following a story he had found in Servius's commentary on Virgil, he reminds Cicero of his own proclamation that Virgil was "magne spes altera Rome" ("second hope of mighty Rome"), which Virgil inserts into the Aeneid $12.168 .{ }^{88}$ While alter clearly has a diachronic sense when used by Virgil in Eclogues 5.49 and Giovanni del Virgilio, who applies it to Dante, in Carmina 3.33-34, Petrarch uses alter to suggest not temporal succession (and supersession), whereby Dante or Statius surpasses Virgil just as Petrarch surpasses Cicero, but synchronic alternatives along generic lines. ${ }^{89}$ In Fam. 24.3, Petrarch embraces time and succession because, even as it reveals his dependence on Dante, it allows for his superiority, but in Fam. 24.4, he

${ }^{86}$ Cicero, 1914, 170-71 (De finibus 2.25). This Ciceronian source will become a favorite of Petrarch's. In his De ignorantia Petrarch, 2003, quotes Cicero on Epicurus (234), and laments that Cicero didn't know the true God (274), despite his apparently monotheistic views (286-92). The more general claim occurs at the beginning of the work: "It all boils down to Augustine's observation about his friend Ambrose: 'I began to love him, not as a teacher of the truth, but as one kindly disposed toward me.' Cicero felt the same way about Epicurus. In many passages, he commends his behavior and courage, but he always condemns his intellect and rejects his doctrine": Petrarch, 2003, 234-35 (De ignorantia 13). Petrarch also mentions Cicero's dual stance on Epicurus in Petrarch, 1934, 169 (Rerum memorandum libri 3.77.18), which is also mentioned by Baranski, 48 .

${ }^{87}$ This use of dux recalls Fam. 21.15.

${ }^{88}$ Virgil, 1918, 310-11. Petrarch uses Seneca, 1974, 1:382-83 (Controversiae 3 praef. 8 ), to express an idea about two realms of eloquence. In his copy of Servius's commentary on the Eclogues 6.11, Petrarch would have found the story that Cicero remarked "magnae spes altera Rome" upon hearing Virgil's Eclogues and that Virgil quotes Cicero's remark when he uses it of Ascanius in Aeneid 12.168. Petrarch places an elaborate flower in the margins next to this passage: see Petrarch, 2006, 2:526; Feo, 1984-, 71. Petrarch also underlines the names of Cicero and Virgil in the passage. A contrasting case occurs in Fam. 24.12 where he defends Virgil's failure to acknowledge Homer in the Aeneid by claiming that Virgil had intended to do for Homer what Statius did for Virgil at the end of the Thebaid.

${ }^{89}$ Servius already interprets the verse as an allegory of literary history that refers to Theocritus and Virgil. For further discussion of Petrarch's use of other classical stories about reception in this letter, see Hinds, 2004. On the influence of del Virgilio on Petrarch, see Ascoli, 2009. For more on the significance of alter, see Feo, 1984-. 
seeks to erase time by establishing two alternative spheres of eloquence: poetry and prose..$^{90}$

Petrarch's two letters to Cicero (Fam. 24.3-4) thus adopt strategies of narrative and nonnarrative that Barolini has identified as defining, dialectical poles in Petrarch's lyrics. ${ }^{91}$ In Fam. 24.3 he embraces the narrative of supersession that he takes from Dante, while in Fam. 24.4 he adopts a synchronic strategy of generic models. Petrarch himself suggests a parallel between his classical studies and his poetry for Laura in the only letter of the Familiares that explicitly discusses her, Fam. 2.9. ${ }^{92}$ In this letter Petrarch addresses the problem of the place of the classics for a Christian intellectual, which he discusses through the lens of Jerome's dream of coming before God to be accused of being a Ciceronian. In the larger context of the millennial confrontation between classical and Christian works, beginning with Tertullian who thinks that the correct response to the question "What has Athens to do with Jerusalem?" is "nothing," Petrarch aligns himself with Augustine who, according to Petrarch, never had Jerome's anxieties and was even converted through reading Cicero's now-lost Hortenius. ${ }^{93}$ In the next part of the letter, Petrarch turns to defending the reality of Laura. ${ }^{94}$ It is remarkable that these

${ }^{90}$ At the end of the letter, Petrarch does return to the idea of succession, but only insofar as Latins are superior to Greeks. In other words, he moves away from the question of succession within a tradition, but succession from one tradition to another, in keeping with the medieval idea of translatio studii.

${ }^{91}$ Ascoli, 2011, 56n66, notes how Barolini's analysis of the narrative and anti-narrative elements of Petrarch's lyrics could be applied to a reading of Petrarch's letters as well. Rossi, 1930, 110, also intuits the connection between book 24 and Petrarch's poems for Laura. For the problem of time as Petrarch's major metaphysical and therefore philosophical concern, see Barolini, 2009b and 2009c as well as the foundational Barolini, 2006: "In other words, Petrarch's acceptance of the dictates of narrative is governed by his nonacceptance: in part 1 narrative is avoided because the goal is to stop time, resist death; in part 2 narrative is invoked because in order to preserve her as she was he must preserve her in time. He thus adopts opposite and apparently contradictory strategies to achieve the same results. When she is alive, he needs to cancel time. When she is dead, he needs to appropriate it. So, Petrarch both evades narrativity and confronts it because both postures figure in his dialectical struggle to overcome the forces of time": Barolini, 2006, 222. For a broader genealogy of the theme of the triumph of time, see Folena.

${ }^{92}$ In this same letter (Fam. 2.9), Petrarch also evokes Scipio and thus the Africa.

${ }^{93}$ Augustine, 1998, 39 (Confessions 3.4.7). Petrarch's somewhat distorted account of the relationship between Hortensius and Augustine's conversion strengthens the intriguing parallel to the Statius-Virgil story. The locus classicus for Augustine's defense of the use of pagan learning is De Doctrina 2.40.60, where he describes it as similar to the Israelites stealing gold from Egyptians: see Augustine, 1995, 125.

${ }^{94}$ For Fam. 2.9, see Petrarch, 1975-85, 1:98-106. For a discussion of Laura's resonance with Scipio, see Bernardo, 1962, 62. 
two parts of the letter have been so rarely connected. To insist on the reality of Laura, whose name associates her with the classical laurea, is, in a sense, to insist on the reality of the past. As Barolini suggestively remarks in a comparison of Dante and Petrarch: "Unlike Beatrice, who exists in an iconic present until she dies, when she is reborn into an even more potent present tense, Laura exists primarily in the past." 95 Indeed, following the association Petrarch implies in Fam. 2.9, one could argue that Laura is the past.

The link between Laura and the classical past that Petrarch suggests in Fam. 2.9 is corroborated by two other shared features of his relationships with Laura and Cicero: an emphasis on the dates of the encounters and the persistence of the wounds that both encounters inflict. Petrarch's emphasis on the date in the explicit to Fam. 24.3 not only echoes Dante's description of Virgil in Inferno 1, as already mentioned, but also represents the first time in the whole collection, after over 300 letters, that Petrarch includes the year, thus situating in time the forgetting of time (temporum oblitus) brought on by this discovery. ${ }^{96}$ Petrarch's emphasis on the precise date recalls the notation of his first vision of Laura on 6 April 1327 when, he writes, "I entered the labyrinth, nor do I see where I may escape," using an image that provides the title for this essay. ${ }^{97}$ Similarly, both encounters result in wounds. While the wounds from his love for Laura fit into the conventions of lyric discourse, the Ciceronian wound is new. According to Petrarch, the codex containing his transcriptions of the Ciceronian letters he discovered continually attacked him. ${ }^{98}$ The connection between this literal wound inflicted by the Ciceronian volume, which he describes in his letter to Boccaccio about the incident (Lettera Dispersa 46), is made by his use of the same verb offendere that he had deployed for his intellectual wound in Fam. 1.1. ${ }^{99}$ As he puts it at the

${ }^{95}$ Barolini, 2009b, 205.

${ }^{96}$ Antognini, 297.

${ }^{97}$ Petrarch, 1976, 365 (Rvf 211).

${ }^{98}$ For a discussion of surviving material evidence of Petrarch's copies of Cicero, see Billanovich, 1996. The medieval model for the success of such saintly tears about the salvation of a pagan is the tale of Gregory and Trajan, which, according to Dante and the Golden Legend, was successful since Trajan was saved.

${ }^{99}$ Petrarch, 1994, 338-59; Petrarch, 1975-85, 12-13, uses offendere one other time in Fam. 1.1 to describe how his father carried him to protect his body (ne contactu tenerum corpus offenderet), just as Metabus protected Camilla in Aeneid 11.544, which would make Petrarch into the Camilla figure. For interpretations of Petrarch's wound, see Hinds, 2004 and 2005; and Martinez, 2010. Ibid., 57, interprets the attack of Cicero on Petrarch "as a displaced scenario for Petrarch's complex ambivalence about fatherhood, filiation, and literary imitation." 
end of Fam. 21.10: "My beloved Cicero has now wounded my leg as he once did my heart." 100

Just as they are united by precise dating and shared effect, the discursive spheres contaminate as well. Petrarch's pursuit of Laura's traces and his hunt for the classical past share an erotics most visible in the later letters to Virgil and Homer. ${ }^{101}$ In his letter to Virgil (Fam. 24.11), for example, Petrarch both implicitly questions Dante's placement of the classical poet in the otherworld and traces Virgil's footsteps just as he does Laura's in "Chiare, fresche, et dolci acque" (Rvf126) and throughout the second half of the Rerum vulgarium fragmenta. ${ }^{102}$ In the letter to Homer (Fam. 24.12), which includes yet another discussion of the distinction between Virgil and Cicero in their respective genres, Petrarch first describes himself as like Penelope waiting for Ulysses to return and then turns Homer into a Laura-like beloved with streaming hair: "Already I had gradually lost all hope, for, aside from some opening lines of several of your poems, in which I viewed you as one beholds from a distance the uncertain and shimmering look of a desired friend or a glimpse of his streaming hair, nothing of yours had reached me in Latin." 103

These parallels suggest the continuities between Petrarch's vernacular and Latin production, but the traces of the classics are different from the traces of Laura, of course, because they can be discovered in book form. (And one could argue that Petrarch's collection of his vernacular lyrics for Laura in the Rerum vulgarium fragmenta is a complementary attempt to give book form to her traces: he makes a book to contain the past

${ }^{100}$ Petrarch, 1975-85, 3:188 (Fam. 21.10). Also in ibid., 3:186 (Fam. 21.10), Petrarch laments Cicero's lack of faith in explicit comparison with Paul's weeping over the grave of Virgil: "I admit that Cicero could not know Christ, having passed away just before Christ became man. His fate is surely worthy of tears, for had this man of truly lofty and divine intelligence seen Christ or heard His name, in my opinion he would not only have believed in Him but with his incomparable eloquence would have been His greatest herald, as the apostle Paul, weeping, reportedly said about the other prince of Latin eloquence, the poet Virgil, upon visiting his tomb."

${ }^{101}$ The book becomes the material reminder of the attractions of antiquity, which Petrarch explicitly links to Laura in Fam. 2.9.

${ }^{102}$ Petrarch, 1976, 244-47. For Fam. 24.11 as a critique of Dante, see Usher. For a comparison of Fam. 24.11 and $R v f 126$, see Greene, 88-93. For a reading of $R v f 129$ and Fam. 4.1, see Ascoli, 2011, 21-58. Barolini, 2006, 217-18, notes the pursuit of traces of Laura as exemplary of the impulse toward narration in part 2, referring to $R v f 280,288,301$, 304, 305, 306, and 320.

${ }^{103}$ Petrarch, 1975-85, 3:342. The intriguing gender of this desire deserves more attention than can be given to it here. 
Laura just as he tries to recover books from the actual past.) At the end of Fam. 24.4 Petrarch underlines his interest in the material remains of the past with a list of Cicero's books that have survived or have been lost: "here are the titles of those whose loss is most to be deplored: De republica, De re familiari, De re militari, De laude philosophie, De consolatione, and De gloria, although my feeling is one of faint hope for the last ones rather than total despair." ${ }^{\text {104 }}$ At least one of Petrarch's contemporaries and followers was particularly attracted to this material information. In his copy of the Familiares, Lapo da Castiglionchio the Elder (1316-81) marks this passage in particular and rewrites the lists of titles in the lower margin. ${ }^{105}$ This precision may be the real difference between Dante and Petrarch. As in his reconstruction of Livy, Petrarch developed new philological and scholarly techniques that Dante does not seem to have imagined. ${ }^{106}$ What is new is less the historical selfconsciousness than its taking form and expression in certain methods that would be identified with modern scholarship. ${ }^{107}$

Petrarch's catalogue suggests that he is interested in a new set of questions and concerns, but the way he describes his historical selfconsciousness derives from Dante. Petrarch's anticipation of modes of modern scholarship make him a far safer (and imitable) model than Dante's visionary encounter with the classical, contemporary, and celestial. Whereas Dante sees all substances and accidents bound by love in a single volume, Petrarch provides a model for historical inquiry that was not based on a vision that transcends history. In a sense, Petrarch's hunt for material texts literalizes Dante's "cercar lo tuo volume" (Inf. 1.84), from "searching through" Virgil's volume to searching for

${ }^{104}$ Ibid., 3:320-21.

${ }^{105}$ Biblioteca Medicea Laurenziana, Florence, Plut. 26 sin. 10, c. $166^{v}$. Petrarch addresses his famous letter on the scarcity of copyists (Fam. 12.8) to Lapo, as well as a longer letter that alludes to several Ciceronian works. Petrarch also borrowed some Ciceronian works from Lapo in 1351 and kept them for four years; see Petrarch, 1975-85, 3:62-64 (Fam. 18.11-12); and Foresti, 242-50.

${ }^{106}$ For praise of Petrarch's textual critical accomplishments, see Sandys, 2:16; Pfeiffer, 21-23; Reynolds and Wilson; Rico, 49. For a more detailed discussion of Livy, see Billanovich, 1951. For a more recent and balanced view of Petrarch's philological accomplishments, see Fera.

${ }^{107}$ In other words, one could define Petrarch's novelty in terms of the birth of the documentary method that others, like Carruthers, 8 , have marked as the defining move away from the medieval world and that historians of antiquity see as the difference between Herodotus and Thucydides. On this topic, see also Momigliano on antiquarians; Le Goff on the emergence of the documentary method; Most in Timpanaro, 1-32; and J. W. Burrow. For the later development of these scholarly methods, see Grafton, 1985. 
Cicero's. ${ }^{108}$ Entering the labyrinth of the library is not without its perils: one can be wounded both intellectually and physically. ${ }^{109}$ Petrarch's quotation of Dante suggests that the accent has been misplaced in the historiography: it is not a new vision of the past, but a different materialization of it that will take on new forms and practices. ${ }^{110}$ For Petrarch, the book is not only an ideal form from which one transcribes, as it is for Dante at the beginning of the Vita nuova, or which can be used as a symbol, as it is at the end of the Paradiso, but also a material object that may contain the past.

\section{The Afterlife of the Image: Boccaccio and Bruni}

Although Petrarch never saw his period as one of rebirth, he does seem to have imagined such an age would follow him, and many later writers would give Petrarch a privileged position in this historical development. ${ }^{111}$ In his De Vita Petracchi, however, Boccaccio portrays Petrarch as fulfilling the

${ }^{108}$ Dante, 1:31. The transformation occurs at the beginning of his first letter to Cicero: "Francesco sends his greetings to his Cicero. After a lengthy and extensive search for your letters, I found them where I least expected, and I then read them with great eagerness. I listened to you speak on many subjects, complain about many things, waver in your opinions, O Marcus Tullius": Petrarch, 1975-85, 3:317. According to a search on the Dartmouth Dante Project, the first commentator to think the verb cercar required a gloss is Paolo Costa (1819-21), "cercar, cioè attentamente considerare."

${ }^{109}$ Petrarch tries to bring back the ancients in many ways: staging coronations, writing histories, changing Latin style, altering writing technique, and even using classical names like Socrates for friends. For examples of the fervor of later book hunters, see Gordan. The appeal of this narrative strategy persists in the modern schoolroom, textbook, and in popular accounts, like Greenblatt.

${ }^{110}$ Petrarch acknowledges Statius as his most recent precursor for the Roman laurel in his Coronation Oration, but his only intervention in Statian philology does not reflect his vaunted philological perspicacity. In an oblique response to a query from Nelli about Dante's implicit claim that the Achilleid is incomplete, Petrarch argues that Statius has completed both poems: "Some add another poet to these [i.e., Virgil, Lucretius, and Lucan], one whom you may not know but is dear to me, Papinius Statius; but they are mistaken, for he brought both his works to completion": Petrarch, 1975-85, 2:434 (Sen.11.17). Since, as Nolhac, 1:196-97, notes, Petrarch did not know the Sylvae, he seems to view the Achilleid as complete. Nolhac defends Petrarch's view as simply being that of his time, but Nelli's query demonstrates that Dante's suggestion had some influence. For discussion, see Alessio.

${ }^{111}$ See Mommsen; as well as McLaughlin, 1988. Mommsen, 240: "He holds that there was an era of 'pure radiance' in the past, Antiquity, and that there is an era of 'darkness' succeeding this former period and lasting to the poet's own days. Thus, in Petrarch's opinion, there exists, for the time being, only a twofold division of history. But, since he hopes for the coming of 'a better time,' the conception of a third era is expressed, or at least implied, in his thoughts." Cf. Starn, 132: "Even if Petrarch did invent the 'Dark Ages,' he did not think he was living in a Renaissance; and while Petrarch's successors often thought of 
prophecy of Virgil's Eclogue 4 since Petrarch's coronation "surely seemed to everyone that the reign and happy times of Saturn, lost a long time before, had returned." "112 According to Petrarch's account, Boccaccio also seems to have claimed that Petrarch was the equal of both Virgil in poetry and Cicero in prose, and Salutati made the same assertion. ${ }^{113}$ Later biographies of Petrarch will be more ambivalent in their praise. ${ }^{114}$ Whereas Boccaccio saw Petrarch as fulfilling Virgil's prophecy, Leonardo Bruni sees Petrarch as a prophet. In his Life of Petrarch, he writes: "Francesco Petrarca was the first with a talent sufficient to recognize and call back to light the antique elegance of the lost and extinguished style. Admitted it was not perfect in him, yet it was he by himself who saw and opened the way to its perfection, for he rediscovered the works of Cicero, savored and understood them; he adapted himself as much as he could and as much as he knew how to that most elegant and perfect eloquence. Surely he did enough just in showing the way to those who followed it after him." ${ }^{115}$ More or less repeating Petrarch's own claims in Fam. 1.1, Bruni connects Petrarch's discovery of Cicero and the idea of imitation, but he also adds a limitation: Petrarch was the first to bring back the light, but did not perfect it; instead he opened the way for others to follow. ${ }^{116}$ Bruni thus puts Petrarch into the same position that Petrarch had placed Cicero, and Dante had

themselves as Renaissance men, they did not necessarily make clearcut distinctions when it came to actually writing history." Also see Vickers.

${ }^{112}$ Boccaccio, 2004, 80-81 (De Vita 16).

${ }^{113}$ Petrarch, 1975-85, 2:651 (Sen. 17.2): "For you say and advise that it should be enough for me - I use your very words to the letter — to have perhaps equaled Virgil in poetry and Tully in prose." Petrarch's remark curiously occurs as part of an introduction to his translation of Boccaccio's vernacular prose. Salutati also celebrates Petrarch for having excelled in both genres in a pre-1360 letter to Nelli, quoted in Ullman, 108, who notes that Salutati "seems at one time to be sincere in his belief that Petrarch was a greater poet than Virgil and as great a prose writer as Cicero."

${ }^{114}$ Boccaccio may be combining Dante's Statius and Petrarch's own self-identification with the Roman poet in his Coronation Oration: "For we do not read that anyone has been decorated with this honor since the illustrious poet Statius, who flourished in the time of Domitian": Wilkins, 1245. The idea of a modern poet being another Statius, of course, is one that begins with Dante and his concern with the laurel crown. For more on the laurel, see Sturm-Maddox.

${ }^{115}$ Bruni, 97; Solerti, 288: "Francesco Petrarcha fu il primo che hebbe tanta gratia d'ingegno, che rivocò in luce l'antica leggiadria dello stilo perduto e spento; et posto che in lui perfecto non fosse, pure da se vidde, et aperse la via a questa perfettione, ritrovando l'opere di Tullio, et (quelle gustando, et intendendo, adaptandosi quanto potè et seppe a quella elegantissima, et perfectissima facundia. Et per certo fece assai, solo ad mostrare la via ad quelli, che dopo lui dovevano seguire." In Bruni's Dialogi, Niccolò Niccoli similarly criticizes Petrarch for having seen the correct style but failing to achieve it.

${ }^{116}$ Bruni's image of Petrarch "opening the way" derives from Boccaccio's letter to Pizzinga; see Boccaccio, 1992, 666-68 (Epistle 19). 
Virgil. ${ }^{117}$ The danger of the model of supersession is that one can also be surpassed. ${ }^{118}$

Like Bruni, later authors would also celebrate Petrarch using the same delimiting praise that Petrarch had used for Cicero, and Dante for Virgil. ${ }^{119}$ Other scholars would see him as "the prophet of the new age, the ancestor of the modern world" (Voigt), Columbus (Symonds), Moses (Baron), and Copernicus (Panofsky, Greene, Schiffman). ${ }^{120}$ For these critics, Petrarch is a foundational but also transitional figure. Their images express the idea that Petrarch saw something new but did not fully realize what it was. For Kristeller, "Petrarch was both medieval and modern, and as he once stated himself, he looked backward and forward at the same time, as if placed at the frontier of two countries." ${ }^{121}$ In other words, Petrarch was, as Ascoli has argued, in the middle. ${ }^{122}$

${ }^{117}$ For Bruni, Petrarch's rejection of Cicero's political engagement is a mistake and this embrace of Cicero as a model of what Baron called civic humanism would characterize Bruni's own brand of humanism. Bruni insists on this civic dimension in his rewriting of Boccaccio's Life of Dante as well. This civic impulse had already been celebrated by Brunetto Latini (1220-94). As Witt, 2000, 205, notes: "Had Petrarch known this Florentine Cicero, he would have been less shocked upon discovering the ancient Roman's political activity in the pages of Cicero's letters in Ad Atticus." See Baron, 1966; and Hankins, 1995. For a more in-depth analysis of Bruni's Lives, see Ianziti. Also see Bruni's Dialoghi, where "Petrarch is praised over Virgil and Cicero only in the literary forms in which they neither excelled nor staked their fame" by Bruni's Niccolò Niccoli: Quint, 440. Biddick.

${ }^{118}$ For an analysis of this logic, which is at the center of typological and figural thinking, see

${ }^{119}$ One finds the same idea of opening the road in Flavio, 1:46-47, which as Witt, 2000, 304, notes is clearly influenced by Bruni.

${ }^{120}$ Baron, 1958, 28. Petrarch's disappointment with Cicero's political involvement is what excludes Petrarch from being a part of what Baron calls civic humanism, which he sees as beginning with Salutati and Bruni. Ferguson criticizes Baron precisely for the exclusion of Petrarch. For a critique of Baron that emphasizes continuities with the medieval world in the embrace of a civic use of rhetoric, see Skinner. For another discussion of the continuities in the use of Cicero between the medieval and Renaissance, see Nederman. For a volume of reappraisals of Baron, see Hankins, 2000. For Columbus, see Symonds, 62. Petrarch's new awareness of anachronism and discovery of history has been described as Copernican, by Panofsky; Greene; and Schiffman. Panofsky's position has had the widest circulation, mentioned by Nagel and Wood; De Grazia 2007 and 2010; and Grafton, in his foreword in Schiffman, x.

${ }^{121}$ Kristeller, 1978, 13. Kristeller's footnote indicates Rerum memorandum libri 1.19 .4 (see Petrarch, 1934, 19): "like one positioned on the boundary of two peoples, looking forwards and backwards at the same time" ("velut in confinio duorum populorum constitutus ac simul ante retroque prospiciens"). The phrase also suggests the letter on Mt. Ventoux (Fam. 4.1). On this phrase, see Gilson, who argues that Petrarch sees himself more at the dusk of the Middle Ages than the dawn of a new age.

${ }^{122}$ See Ascoli, 2011, 21-58. 
In an argument that has frequently been quoted by other scholars, Thomas Greene claims that Petrarch was "the first to notice that classical antiquity was very different from his own medieval world, and the first to consider antiquity more admirable. Even if anticipations of these attitudes may be found, he was the first to publicize them so effectively as to influence profoundly his immediate posterity." ${ }^{23}$ This article has argued that Dante's vision of history also had its influence, most prominently on Petrarch himself. Petrarch may foresee future ways of looking at the past in the scholarly methods and forms he develops, but he perceives and describes his relation to that past through a Dantean lens. Petrarch's borrowing from Dante in his first letter to Cicero does not make Petrarch more medieval, but reveals instead how the complexity of Dante's construction of his relationship to the past informed the Renaissance idea of history, as his multifaceted portrait of Virgil with its historical basis, its imagined intimacy, its light, and its failings shaped Petrarch's construction of his Cicero.

DUKE UNIVERSITY

${ }^{123}$ Greene, 90 . The passage is quoted by Gouwens; De Grazia, 2010; and Schiffman. 


\section{Bibliography}

Agamben, Giorgio. "What is a Paradigm?" http://www.egs.edu/faculty/giorgioagamben/articles/what-is-a-paradigm/. 2002.

Alessio, Gian Carlo. "La 'Comedìa' nel margine dei classici." In Studi di filologia medievale offerti a D'Arco Silvio Avalle, 3-25. Milan, 1996.

Antognini, Roberta. Il progetto autobiografico delle Familiares di Petrarca. Milan, 2008.

Ascoli, Albert Russell. Dante and the Making of a Modern Author. Cambridge, 2008.

_. "Blinding the Cyclops: Petrarch after Dante." In Petrarch and Dante (2009), 114-73.

- A Local Habitation and a Name: Imagining Histories in the Italian Renaissance. New York, 2011.

Auerbach, Erich. Scenes from the Drama of European Literature. 1959. Reprint, Minneapolis, 1984.

Augustine. De Symbolo Ad Catechumenos Sermo Alius. In vol. 40 of Patrologia Latina, ed. J. P. Migne, 627-68. Paris, 1845.

- De Doctrina Christiana. Trans. R. P. H. Green. Oxford, 1995.

- Confessions. Trans. Henry Chadwick. New York, 1998.

Baglio, Marco. "Presenze dantesche nel Petrarca latino." Studi petracheschi 9 (1992): 77-136.

Baranski, Zygmunt G. "The Ethics of Ignorance: Petrarch's Epicurus and Averroës and the Structures of De Sui Ipsius et Multorum Ignorantia." Proceedings of the British Academy 146 (2007): 39-59.

Barkan, Leonard. Unearthing the Past: Archaeology and Aesthetics in the Making of Renaissance Culture. New Haven, 1999.

Barolini, Teodolinda. Dante's Poets: Textuality and Truth in the Comedy. Princeton, 1984.
. "The Making of a Lyric Sequence:

Time and Narrative in Petrarch's Rerum vulgarium fragmenta." In Dante and the Origins of Italian Literary Culture, 193-223. New York, 2006.

—. "'Only Historicize': History, Material Culture, and the Future of Dante Studies." Dante Studies 127 (2009a): 37-54.

-. "Petrarch as the Metaphysical Poet Who Is Not Dante: Metaphysical Markers at the Beginning of the Rerum vulgarium fragmenta (Rvf 1-21)." In Petrarch and Dante (2009b), 195-225.

-. "The Self in the Labyrinth of Time: Rerum vulgarium fragmenta." In Petrarch: A Critical Guide to the Complete Works (2009c), 33-62.

Baron, Hans. "Moot Problems of Renaissance Interpretation: An Answer to Wallace K. Ferguson." Journal of the History of Ideas 19.1 (1958): 26-34.

- The Crisis of the Early Italian Renaissance: Civic Humanism and Republican Liberty in an Age of Classicism and Tyranny. Princeton, 1966.

Bernardo, Aldo S. Petrarch, Scipio and the "Africa": The Birth of Humanism's Dream. Baltimore, 1962.

- Petrarch, Laura, and the Triumphs. Albany, 1974.

Biblioteca Medicea Laurenziana, Florence, Plut. 26 sin. 10.

Biddick, Kathleen. The Typological Imaginary: Circumcision, Technology, History. Philadelphia, 2003.

Billanovich, Giuseppe. Petrarca letterato I: Lo scrittoio del Petrarca. 2nd ed. Rome, 1947.

$\rightarrow$. "Petrarch and the Textual Tradition of Livy." Journal of the Warburg and Courtauld Institutes 14.3/4 (1951): 137-208. 
. "Petrarca e il Ventoso." Italia medioevale e umanistica 9 (1966): 389-401.

— . "Quattro libri del Petrarca e Verona." Studi petracheschi 7 (1990): 233-62.

_ . "Petrarca e Cicerone." In Petrarca e il primo Umanesimo, 97-116. Padua, 1996.

_- "Petrarca e i libri della cattedrale di Verona." In Petrarca, Verona, e l'Europa: Atti del convegno internazionale di studi, ed. Giuseppe Billanovich and Giuseppe Frasso, 117-78. Padua, 1997.

Black, Robert. "The Donation of Constantine: A New Source for the Concept of the Renaissance?" In Language and Images of Renaissance Italy, ed. Alison Brown, 51-85. Oxford, 1995.

Bloom, Harold. The Anxiety of Influence: A Theory of Poetry. Oxford, 1973.

Blumenberg, Hans. "Light as a Metaphor for Truth: At the Preliminary Stage of Philosophical Concept Formation." In Modernity and the Hegemony of Vision, ed. David Michael Levin, 30-62. Berkeley, 1993.

Boccaccio, Giovanni. Epistole. In vol. 5 of Tutte le opere di Giovanni Boccaccio, ed. Ginetta Auzzas, 493-878. Milan, 1992.

- Vita di Petrarca. Ed. Gianni Villani. Rome, 2004.

Bosco, Umberto. "Né dolcezza di figlio." In Dante vicino, 173-96. Rome, 1976.

Brownlee, Kevin. "Power Plays: Petrarch's Genealogical Strategies." Journal of Medieval and Early Modern Studies 35 (2005): 467-88.

Bruni, Leonardo. "The Lives of Dante and Petrarch." In The Humanism of Leonardo Bruni: Selected Texts, ed. Alan F Nagel, 85-100. Binghamton, 1987.

Burckhardt, Jacob. The Civilization of the Renaissance in Italy. Trans. Peter Murray. New York, 1990.
Burke, Peter. The Renaissance Sense of the Past. London, 1969.

Burrow, John A. The Ages of Man: A Study in Medieval Writing and Thought. Oxford, 1988.

Burrow, John W. A History of Histories: Epics, Chronicles, Romances and Inquiries from Herodotus to the Twentieth Century. New York, 2007.

The Cambridge Companion to Renaissance Humanism. Ed. Jill Kraye. Cambridge, 1996.

Capodivacca, Angela Matilde. "Nietzche's Zukunftsphilologie: Leopardi, Philology, History." California Italian Studies Journal 2.1 (2011). http://www. escholarship.org/uc/item/2528k6vm.

Carrara, Enrico. "Le Antiquis Illustrioribus." In Studi petrarcheschi ed altri scritti, 137-79. Turin, 1959.

Carruthers, Mary. The Book of Memory: A Study of Memory in Medieval Culture. Cambridge, 1990.

Celenza, Christopher S. The Lost Italian Renaissance: Humanists, Historians, and Latin's Legacy. Baltimore, 2004.

Charity, A. C. Events and Their Afterlife: The Dialectics of Christian Typology in the Bible and Dante. Cambridge, 1966.

Chenu, M.-D. "Theology and the New Awareness of History." In Nature, Man, and Society in the Twelfth Century, ed. Jerome Taylor and Lester K. Little, 162-201. Toronto, 1997.

Cicero, Marcus Tullius. De finibus bonorum et malorum. Ed. H. Rackham. Cambridge, 1914.

- Letters to Quintus and Brutus; Letter to Octavian; Invectives; Handbook of Electioneering. Ed. and trans. D. R. Shackleton Bailey. Cambridge, MA, 2002.

Comparetti, Domenico. Vergil in the Middle Ages. Princeton, 1997.

Constable, Giles. Letters and LetterCollections. Turnhout, 1976. 
Cook, Albert S. "Miscellaneous: Dante Purgatorio 22.67-69." Romanic Review 8 (1917): 463.

Cosenza, Mario Emilio, ed. Petrarch's Letters to Classical Authors. Chicago, 1910.

Dante. The Divine Comedy. Ed. and trans. Robert M. Durling. 3 vols. Oxford, 1996-2011.

Davis, Charles Till. Dante's Italy and Other Essays. Philadelphia, 1984.

Davis, Kathleen. Periodization and Sovereignty: How Ideas of Feudalism and Secularization Govern the Politics of Time. Philadelphia, 2008.

de Grazia, Margreta. "The Modern Divide: From Either Side." Journal of Medieval and Early Modern Studies 37.3 (2007): 453-87.

-. "Anachronism." In Cultural Reformations: Medieval and Renaissance in Literary History, ed. Brian Cummings and James Simpson, 13-32. Oxford 2010.

DellaNeva, JoAnn, ed. Ciceronian Controversies. Cambridge, MA, 2007.

Dempsey, Charles. "Response: 'Historia' and Anachronism in Renaissance Art." The Art Bulletin 87.3 (2005): 416-21.

Durling, Robert M. "The Ascent of Mt. Ventoux and the Crisis of Allegory." Italian Quarterly 18 (1974): 7-28.

Eden, Kathy. "Petrarchan Hermeneutics and the Rediscovery of Intimacy." In Petrarch and the Textual Origins of Interpretation, ed. Teodolinda Barolini and H. Wayne Storey, 231-44. Leiden, 2007.

Feo, Michele. "Francesco Petrarca." In Enciclopedia Virgiliana, 53-78. Rome, 1984-.

- ed. Codici latini del Petrarca nelle biblioteche fiorentine: mostra 19 maggio-30 giugno 1991. Florence, 1991.

- "Petrarca e Cicerone." In Cicerone nella tradizione europea: Dalla tarda antichità al Settecento, Atti del VI Symposium Ciceronianum Arpinas (Arpino 6 maggio 2005), ed. Emanuele Narducci, 17-50. Florence, 2006.

Fera, Vincenzo. "La filologia del Petrarca e i fondamenti della filologia umanistica." In Il Petrarca latino e le origini dell'umanesimo, 367-91. Florence, 1996.

Ferguson, Wallace K. The Renaissance in Historical Thought: Five Centuries of Interpretation. Boston, 1948.

Findlen, Paula, ed. The Italian Renaissance: The Essential Readings. Malden, 2002.

Flavio, Biondo. Italia Illustrata: Text, Translation, and Commentary. Ed. Catherine J. Castner. 2 vols. Binghamton, 2005.

Folena, Gianfranco. "L'orologio di Petrarca." Libri e documenti 5 (1979): 1-12.

Foresti, Arnaldo. Aneddoti della vita di Francesco Petrarca. Ed. Antonia Tissoni Benvenuti. Padua, 1977.

Freccero, John. "Allegory and Autobiography." In The Cambridge Companion to Dante, ed. Rachel Jacoff, 161-80. Cambridge, 1992.

Galligan, Francesca. "Poets and Heroes in Petrarch's Africa." In Petrarch in Britain: Interpreters, Imitators, and Translators over 700 Years, ed. Martin McLaughlin, Letizia Panizza, and Peter Hainsworth, 85-93. Oxford, 2007.

Garin, Eugenio. Italian Humanism: Philosophy and Civic Life in the Renaissance. New York, 1965.

_. "Dante nel Rinascimento." Rinascimento, n.s., 7 (1967): 3-28.

Gilson, Etienne. "Notes sur une frontière contestée. . . III. In confinio duorum populorum." Archives d'histoire doctrinale et littéraire au Moyen Age 33 (1958): 81-88.

Gombrich, E. H. "The Renaissance: Period or Movement?" In Background to the English Renaissance: Introductory Lectures, ed. J. B. Trapp, 9-30. London, 1974.

Gordan, Phyllis Walter Goodhart, trans. Two Renaissance Book Hunters: The 
Letters of Poggius Bracciolini to $\rightarrow$ Ianziti, Gary. "From Praise to Prose: Nicolaus de Niccolis. New York, 1974.

Gouwens, Kenneth. "Perceiving the Past: Renaissance Humanism after the 'Cognitive Turn."' The American Historical Review 103.1 (1998): 55-82.

Grafton, Anthony. "Renaissance Readers and Ancient Texts: Comments on Some Commentaries." Renaissance Quarterly 38.4 (1985): 615-49.

- Forgers and Critics: Creativity and Duplicity in Western Scholarship. Princeton, 1990.

Greenblatt, Stephen. The Swerve: How the World Became Modern. New York, 2011.

Greene, Thomas M. The Light in Troy: Imitation and Discovery in Renaissance Poetry. New Haven, 1982.

Hankins, James. "The 'Baron Thesis' after Forty Years and Some Recent Studies of Leonardo Bruni." Journal of the History of Ideas 56.2 (1995): 309-38.

$\rightarrow \longrightarrow$, ed. Renaissance Civic Humanism: Reappraisals and Reflections. Cambridge, 2000.

Haskins, Charles Homer. The Renaissance of the Twelfth Century. 1927. Reprint, Cambridge, 1971.

Hinds, Stephen. "Petrarch, Cicero, Virgil: Virtual Community in Familiares 24, 4." Materiali e discussioni per l'analisi dei testi classici 52 (2004): 157-75.

$\rightarrow$ _ . "Defamliarizing Latin Literature, from Petrarch to Pulp Fiction." Transactions of the American Philological Association 135.1 (2005): 49-81.

Houghton, Luke. "Veteris vestigia flammae?: The Rebirths of Antiquity." In Renaissance? Perceptions of Continuity and Discontinuity in Europe, c. 1300-c. 1550, ed. Alexander Lee, Pit Péporté, and Harry Schnitker, 17-26. Leiden, 2010. Iannucci, Amilcare A. "Dante's Limbo: At the Margins of Orthodoxy." In Dante and the Unorthodox: The Aethetics of Transgression, ed. James Miller, 63-82. Waterloo, Ontario, 2005.

Leonardo Bruni's Lives of the Poets." I Tatti Studies: Essays in the Renaissance 10 (2005): 127-48.

Jacoff, Rachel, and Jeffrey T. Schnapp, eds. The Poetry of Allusion: Virgil and Ovid in Dante's Commedia. Stanford, 1991.

Jameson, Frederic. Postmodernism, or, the Cultural Logic of Late Capitalism. Durham, 1991.

Jauss, Hans Robert. "Modernity and Literary Tradition." Critical Inquiry 31.2 (2005): 329-64.

Kelley, Donald R. Renaissance Humanism. Boston, 1991.

"Ideas of Periodization in the West." In The Many Faces of Clio: Cross-Cultural Approaches to Historiography, ed. Q. Edward Wang and Franz L. Fillafer, 17-27. New York, 2006.

Kinney, Arthur F. "Continental Poetics." In A Companion to Rhetoric and Rhetorical Criticism, ed. Walter Jost and Wendy Olmsted, 80-95. Malden, 2004.

Kristeller, Paul Oskar. Eight Philosophers of the Italian Renaissance. Stanford, 1978.

_ "Humanism and Scholasticism in the Italian Renaissance [1944]." In Renaissance Thought and Its Sources, 85-105. New York, 1979.

Latini, Brunetto. Il Tesoretto (The Little Treasure). Trans. Julia Bolton Holloway. New York, 1981.

Laureys, Marc. “Quintilian's Judgement of Seneca and the Scope and Purpose of Inst.,10, 1." Antike und Abendland 37 (1991): 100-25.

Le Goff, Jacques. “Documento/monumento.” In Enciclopedia Einaudi, ed. Ruggiero Romano, 38-48. Turin, 1978.

Lokaj, Rodney J., ed. Petrarch's Ascent of Mount Ventoux: The Familiaris IV.1. Rome, 2006.

Lorch, Maristella. "Petrarch, Cicero, and the Classical Pagan Tradition." In Renaissance Humanism: Foundations, 
Forms, and Legacy, ed. Albert Rabil Jr., 71-94. Philadelphia, 1988.

Mann, Nicholas. "The Origins of Humanism." In The Cambridge Companion to Renaissance Humanism (1996), 1-19.

Martinez, Ronald L. "Dante and the Two Canons: Statius in Virgil's Footsteps (Purgatorio 21-30)." Comparative Literature Studies 32.2 (1995): 151-75.

- "Petrarch's Lame Leg and the Corpus of Cicero: An Early Crisis of Humanism?" In The Body in Early Modern Italy, ed. Julia L. Harrison and Walter Stephens, 42-58. Baltimore, 2010.

Mazzocco, Angelo. "Petrarch: Founder of Renaissance Humanism?" In Interpretations of Renaissance Humanism, ed. Angelo Mazzocco, 215-42. Leiden, 2006.

Mazzotta, Giuseppe. The Worlds of Petrarch. Durham, 1993.

-. "Petrarch's Epistolary Epic: Letters on Familiar Matters (Rerum familiarum libri)." In Petrarch: A Critical Guide to the Complete Works (2009), 309-20.

McLaughlin, Martin L. "Humanist Concepts of Renaissance and Middle Ages in the Tre- and Quattrocento." Renaissance Studies 2.2 (1988): 131-42.

- Literary Imitation in the Italian Renaissance. Oxford, 1995.

Menocal, Maria Rosa. Shards of Love: Exile and the Origins of the Lyric. Durham, 1994.

Merton, Robert, K. On the Shoulders of Giants: A Shandean Postscript. 1965. Reprint, Chicago, 1993.

Minnis, Alastair J. Medieval Theory of Authorship: Scholastic Literary Attitudes in the Later Middle Ages. London, 1984. - Fallible Authors: Chaucer's Pardoner and Wife of Bath. Philadelphia, 2008.

Moevs, Christian. The Metaphysics of Dante's Comedy. New York, 2005.
Momigliano, Arnaldo. The Classical Foundations of Modern Historiography. Berkeley, 1990.

Mommsen, Theodor E. "Petrarch's Conception of the 'Dark Ages."' Speculum 17 (1942): 226-42.

Montano, Rocco. Dante e il rinascimento. Naples, 1942.

Morgan, Alison. Dante and the Medieval Other World. Cambridge, 1990.

Nagel, Alexander, and Christopher S. Wood. Anachronic Renaissance. New York, 2010.

Najemy, John M. Between Friends: Discourses of Power and Desire in the MachiavelliVettori Letters of 1513-1515. Princeton, 1993.

Nederman, Cary J. "The Union of Wisdom and Eloquence before the Renaissance: The Ciceronian Orator in Medieval Thought." Journal of Medieval History 18.1 (1992): 75-95.

Noble, Thomas F. X. Western Civilization: Beyond Boundaries. 5th ed. Boston, 2008.

Nolhac, Pierre de. Petrarque et L'humanisme. 2 vols. Paris, 1907.

Ohly, Friedrich. Sensus Spiritualis: Studies in Medieval Significs and the Philology of Culture. Chicago, 2005.

Panofsky, Erwin. Renaissance and Renascences in Western Art. New York, 1979.

Pasquini, Emilio. "Dantismo petrarchesco: Ancora su Fam. XXI 15 e dintorni." In Motivi e forme delle Familiari di Francesco Petrarca, ed. Claudia Berra, 21-38. Milan, 2003.

Petrarch: A Critical Guide to the Complete Works. Ed. Victoria Kirkham and Armando Maggi. Chicago, 2009.

Petrarch and Dante: Anti-Dantism, Metaphysics, Tradition. Ed. Zygmunt G. Baranski and Theodore J. Cachey. Notre Dame, 2009.

Petrarch, Francesco. L'Africa. Ed. Nicola Festa. Florence, 1962. 
Rerum memorandum libri. Ed. Giuseppe Billanovich. Florence, 1934.

- Letters on Familiar Matters: Rerum familiarium libri I-XXIV. Trans. Aldo S. Bernardo. 3 vols. Baltimore, 1975-85.

- Petrarch's Lyric Poems: The Rime Sparse and Other Lyrics. Trans. Robert M. Durling. Cambridge, 1976. . De vita solitaria. Buch I. Ed. K. A. E. Enenkel. Leiden, 1990.

. Letters of Old Age = Rerum senilium libri I-XVIII. Trans. Aldo S. Bernardo, Reta A. Bernardo, and Saul Levin. 2 vols. Baltimore, 1992.

- Lettere disperse. Ed. Alessandro Pancheri. Parma, 1994.

- On Religious Leisure (De otio religioso). Trans. Susan S. Schearer. New York, 2002.

-. Invectives. Ed. and trans. David Marsh. Cambridge, 2003.

- Le familiari = Familiarium rerum libri. Trans. Ugo Dotti. Ed. Umberto Bosco and Vittorio Rossi. 5 vols. Racconigi, 2004-09.

_. Le postille del Virgilio Ambrosiano.

Ed. Marco Baglio, Antonietta Nebuloni Testa, and Marco Petoletti. 2 vols. Rome, 2006.

Pfeiffer, Rudolf. History of Classical Scholarship: From 1300 to 1850. Oxford, 1976.

Porter, James I. Nietzsche and the Philology of the Future. Stanford, 2000.

Pulsoni, Carlo. "Il Dante di Francesco Petrarca: Vaticano Latino 3199.” Studi petrarcheschi 10 (1993): 155-208.

Quillen, Carol E. Rereading the Renaissance: Petrarch, Augustine, and the Language of Humanism. Ann Arbor, 1998.

Quint, David. "Humanism and Modernity: A Reconsideration of Bruni's Dialogues." Renaissance Quarterly 38.3 (1985): 423-45.

Reeve, Michae D. "The Rediscovery of Classical Texts in the Renaissance."
In Itinerari dei testi antichi, ed. Oronzo Pecere, 115-57. Rome, 1991. -. "Classical Scholarship." In The Cambridge Companion to Renaissance Humanism (1996), 20-46.

Regn, Gerhard. "Negotiating Religion and Art: Wagner, Petrarch, Dante." $M L N$ 126 (2011): S77-S88.

Regn, Gerhard, and Bernhard Huss. "Petrarch's Rome: The History of the Africa and the Renaissance Project." MLN 124.1 (2009): 86-102.

Renaudet, Augustin. Dante, humaniste. Paris, 1952.

Reynolds, L. D., and N. G. Wilson. Scribes and Scholars: $A$ Guide to the Transmission of Greek and Latin Literature. 3rd ed. Oxford, 1991.

Rico, Francisco. "Philology and Philosophy in Petrarch." In Intellectuals and Writers in Fourteenth-Century Europe, ed. Piero Boitani and Anna Torti, 45-66. Cambridge, 1986.

Rorty, Richard. Philosophy and the Mirror of Nature. Princeton, 1979.

Rossi, Vittorio. "Un paragone dantesco e petrarchesco [1904].” In Scritti di critica letteraria, 109-16. Florence, 1930.

_. "Sulla formazione delle raccolte epistolari petrarchesche." Annali della cattedra petrarchescha 3 (1932): 55-73.

Rotondi, G. "Note sulle Familiari del Petrarca." Istituto lombardo di scienze e lettere: Rendiconti: Classe di lettere scienze storiche e morali 76 (1942-43): 114-32.

Sandys, John Edwin. A History of Classical Scholarship. 2 vols. Cambridge, 1908.

Schiffman, Zachary Sayre. The Birth of the Past. Baltimore, 2011.

Seneca. Ad Lucilium epistulae morales. Trans. Richard M. Gummere. 3 vols. London, 1925.

-. Declamations. Trans. Michael Winterbottom. 2 vols. Cambridge, MA, 1974. 
Simone, Franco. "La Coscienza della Rinascita negli Umanisti." La Rinascita 2 and 3 (1939 and 1940): 838-71 and 163-86.

Simpson, James. "Subjects of Triumph and Literary History: Dido and Petrarch in Petrarch's Africa and Trionfi." Journal of Medieval and Early Modern Studies 35.3 (2005): 489-508.

Skinner, Quentin. The Foundations of Modern Political Thought. 2 vols. Cambridge, 1978.

Solerti, Angelo. Le Vite di Dante, Petrarca e Boccaccio scritte fino al secolo decimosesto. Milan, n.d. [1904].

Spitzer, Leo. "The Problem of Latin Renaissance Poetry." Studies in the Renaissance 2 (1955): 118-38.

Starn, Randolph. "Who's Afraid of the Renaissance?" In The Past and Future of Medieval Studies, ed. John Van Engen, 129-47. Notre Dame, 1994.

Statius. Thebaid, Books 8-12 and Achilleid. Ed. and trans. D. R. Shackleton Bailey. Cambridge, MA, 2003.

Stierle, Karlheinz. "Translatio Studii and Renaissance: From Vertical to Horizontal Transmission." In The Translatability of Cultures: Figurations of the Space Between, ed. Sanford Budick and Wolfgang Iser, 55-67. Stanford, 1996.

Struever, Nancy S. Theory as Practice: Ethical Inquiry in the Renaissance. Chicago, 1992.

Sturm-Maddox, Sara. "Dante, Petrarch, and the Laurel Crown." In Petrarch and Dante (2009), 290-319.

Symonds, John Addington. The Revival of Learning. Vol. 2, Renaissance in Italy. London, 1877.

Timpanaro, Sebastian. The Genesis of Lachmann's Method. Ed. and trans. Glenn W. Most. Chicago, 2005

Ullman, B. L. "Renaissance: The Word and the Underlying Concept." Studies in Philology 49.2 (1952): 105-18.
Usher, Jonathan. "Petrarch Reads Inferno 4." Electronic Bulletin of the Dante Society of America (2000). http://www.princeton.edu/ dante/ ebdsa/usher2.htm.

Velli, Giuseppe. "Il Dante di Francesco Petrarca." Studi petracheschi, n.s., 2 (1985): 185-99.

Vickers, Brian. "The Idea of the Renaissance, Revisited." Yearbook of the Spanish and Portuguese Society for English Renaissance Studies 12 (2002): 69-95.

Virgil. Eclogues, Georgics, Aeneid 1-6. Trans. H. Rushton Fairclough. London, 1916. . Aeneid 7-12, The Minor Poems. Trans. H. Rushton Fairclough. London, 1918.

Wallace, David. Chaucerian Polity: Absolutist Lineages and Associational Forms in England and Italy. Stanford, 1997.

Wallace, David, and Jennifer Summit, eds. Medieval/Renaissance: After Periodization. Special issue, Journal of Medieval and Early Modern Studies 37 (2007).

Weiss, Roberto. The Renaissance Discovery of Classical Antiquity. 2nd ed. Oxford, 1988.

Wilkins, Ernest H. "Petrarch's Coronation Oration.” PMLA 68.5 (1953): 1241-50.

Witt, Ronald G. "Medieval 'Ars Dictaminis' and the Beginnings of Humanism: A New Construction of the Problem." Renaissance Quarterly 35.1 (1982): 1-35.

- In the Footsteps of the Ancients. Leiden, 2000.

Wojciehowski, Dolora A. Old Masters, New Subjects: Early Modern and Poststructuralist Theories of Will. Stanford, 1995.

Zak, Gur. Petrarch's Humanism and the Care of the Self. Cambridge, 2010.

Ziolkowski, Jan M., and Michael C. J. Putnam, eds. The Virgilian Tradition: The First Fifteen Hundred Years. New Haven, 2008. 